
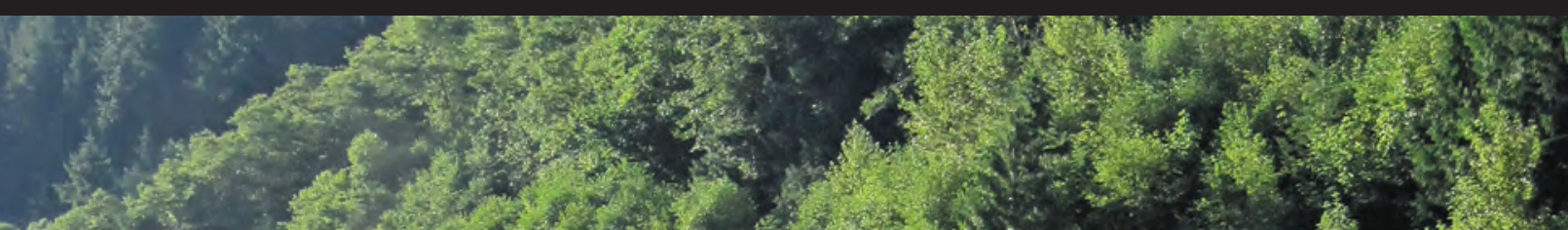

Evaluation of Two Juvenile Salmon Collection Devices at Cowlitz Falls Dam, Washington, 2014
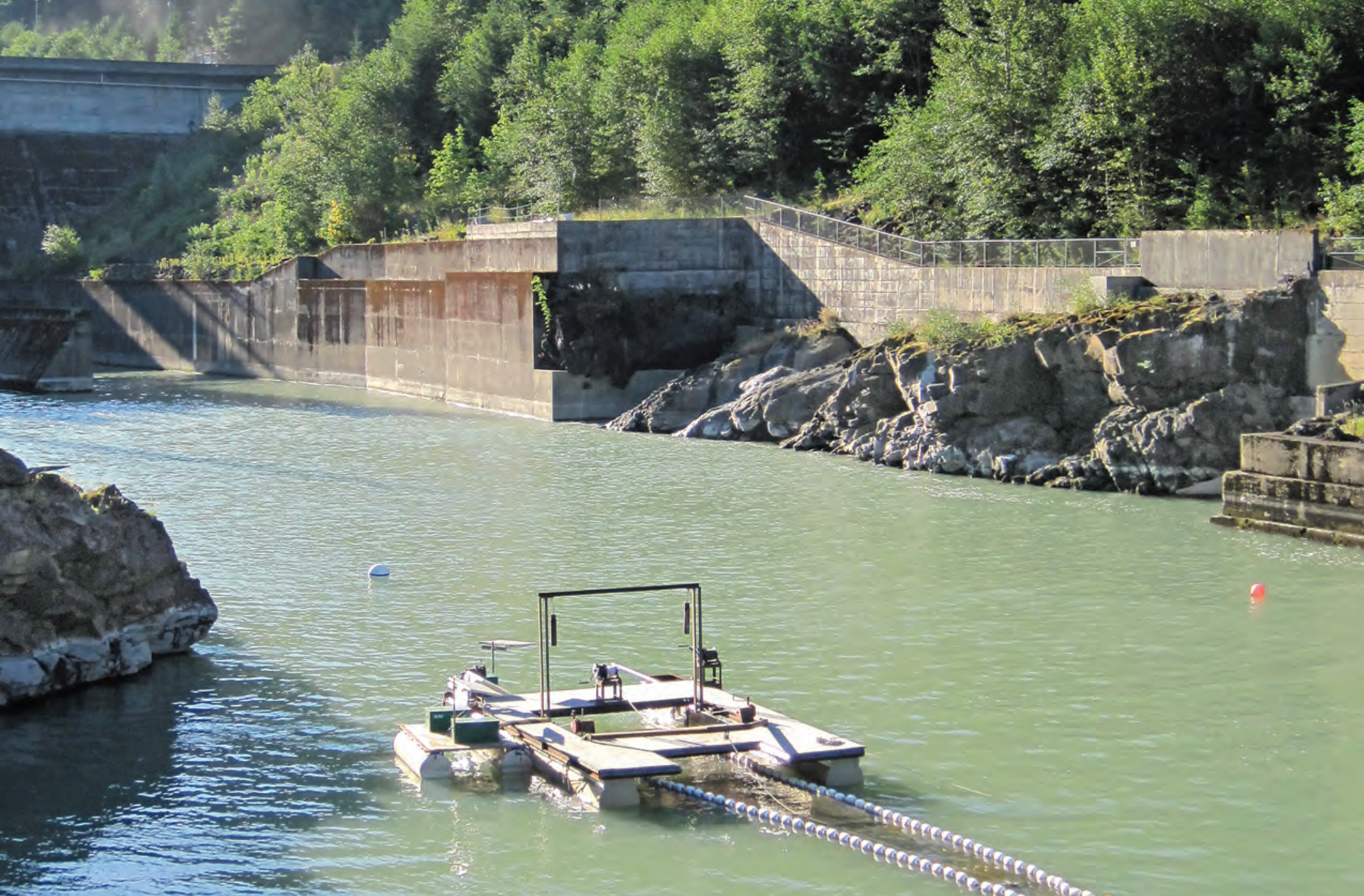

Open-File Report 2015-1054

U.S. Department of the interior U.S. Geological Survey 
Cover: Photographs showing Upper Riffe Lake Collector in the tailrace of Cowlitz Falls Dam, and the weir box in the forebay of Cowlitz Falls Dam (inset). Main photograph was taken by Tobias Kock, U.S. Geological Survey, August 6, 2014; inset photograph was taken by John Serl, Washington Department of Fish and Wildlife, May 15, 2013. 


\section{Evaluation of Two Juvenile Salmon Collection Devices at Cowlitz Falls Dam, Washington, 2014}

By Tobias J. Kock, Theresa L. Liedtke, Brian K. Ekstrom, and William R. Hurst

Open-File Report 2015-1054

U.S. Department of the Interior

U.S. Geological Survey 


\section{U.S. Department of the Interior \\ SALLY JEWELL, Secretary}

\section{U.S. Geological Survey \\ Suzette M. Kimball, Acting Director}

U.S. Geological Survey, Reston, Virginia: 2015

For more information on the USGS-the Federal source for science about the Earth,

its natural and living resources, natural hazards, and the environment-visit

http://www.usgs.gov or call 1-888-ASK-USGS (1-888-275-8747)

For an overview of USGS information products, including maps, imagery, and publications, visit http://www.usgs.gov/pubprod

Any use of trade, firm, or product names is for descriptive purposes only and does not imply endorsement by the U.S. Government.

Although this information product, for the most part, is in the public domain, it also may contain copyrighted materials as noted in the text. Permission to reproduce copyrighted items must be secured from the copyright owner.

Suggested citation:

Kock, T.J., Liedtke, T.L., Ekstrom, B.K., and Hurst W.R., 2015, Evaluation of two juvenile salmon collection devices at Cowlitz Falls Dam, Washington, 2014: U.S. Geological Survey Open-File Report 2015-1054, 30 p., http://dx.doi.org/10.3133/ofr20151054.

ISSN 2331-1258 (online) 


\section{Contents}

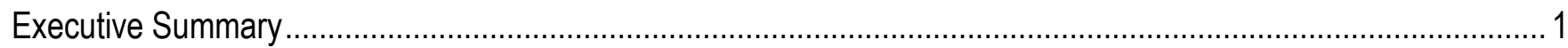

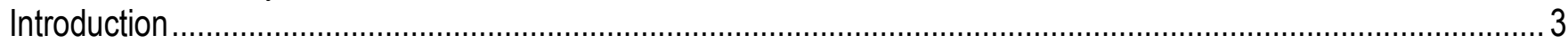

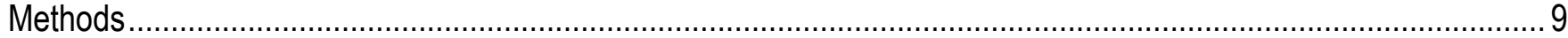

Fish Collection, Tagging, and Release.................................................................................................

Configuration of the Fish Collection System at Cowlitz Falls Dam ................................................................ 10

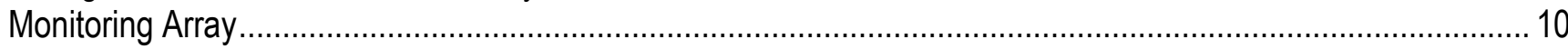

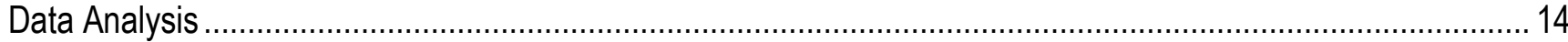

Assessment of Differences between Release Sites ........................................................................... 14

Behavior Patterns, Performance Metrics, and Dam Passage .................................................................. 15

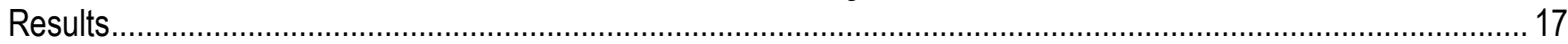

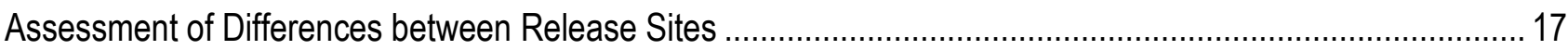

Behavior Patterns, Performance Metrics, and Dam Passage ................................................................. 21

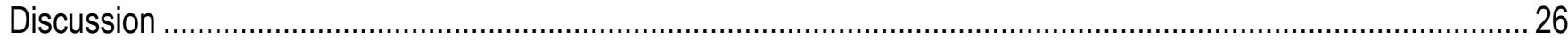

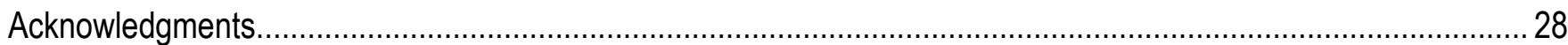

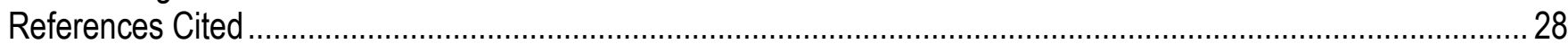

\section{Figures}

Figure 1. Schematic of the study area showing locations of fixed monitoring sites (open circles),

release sites (filled circles), and the Upper Riffe Lake Collector (star), Washington............................................. 4

Figure 2. Schematic of Cowlitz Falls Dam showing locations of the debris barrier and spillbays 2 and 3 , where juvenile salmon collection occurred through flume 1, flume 2, the weir box, and flume 4 ........................... 5

Figure 3. Schematic and photographs of the Upper Riffe Lake Collector deployed in the tailrace of Cowlitz Falls Dam during 2014

Figure 4. Schematic of the side view of spillbay 3 at Cowlitz Falls Dam showing the path of movement that juvenile Chinook salmon would have to take to be collected in flume 4 during July-August 2014

Figure 5. Schematic of Cowlitz Falls Dam and location of general detection zones for an underwater antenna detection array that monitored radio-tagged juvenile Chinook salmon during July-August 2014 ....

Figure 6. Boxplots showing juvenile Chinook salmon fork lengths in millimeters ( $\mathrm{mm}$ ) (top panel) and weights in grams (g) (bottom panel) for groups of fish that were tagged and released at the Cowlitz Falls Day Use Park and Lewis County Public Utility District (PUD) Boat Launch

Figure 7. Graph showing proportion of tagged juvenile Chinook salmon that moved downstream from the Cowlitz Falls Day Use Park and Lewis County Public Utility District (PUD) Boat Launch release sites in Lake Scanewa and entered the forebay of Cowlitz Falls Dam over time (in days [d]).

Figure 8. Graph showing residence time (in days [d]) of tagged juvenile Chinook salmon in the forebay of Cowlitz Falls Dam during July-August 2014 for groups of fish released at the Cowlitz Falls Day Use Park and the Lewis County Public Utility District (PUD) Boat Launch

Figure 9. Graph showing percentage of tagged Chinook salmon that made trips between the collection entrances at Cowlitz Falls Dam during 2014.

Figure 10. Graph showing percentage of tagged Chinook salmon that were collected (filled bars) or passed through turbines (open bars) by hour, at Cowlitz Falls Dam during 2014 


\section{Tables}

Table 1. Summary of release dates, number of fish released, and average sizes of juvenile Chinook salmon released during a radiotelemetry evaluation at Cowlitz Falls Dam, Washington, 2014.

Table 2. Descriptions of performance metrics used to evaluate the collection flumes and weir box during 2014

Table 3. Descriptions of performance metrics used to evaluate the Upper Riffe Lake Collector (URLC) during 2014

Table 4. Percentage of tagged juvenile Chinook salmon that were first detected in arrival zones that were horizontally and vertically stratified across the face of Cowlitz Falls Dam during 2014.

Table 5. Summary of performance metrics for flume $1 /$ flume 2 and the weir box at Cowlitz Falls Dam during 2014

Table 6. Percentage of tagged juvenile Chinook salmon that were first detected in arrival zones that were horizontally and vertically stratified across the face of Cowlitz Falls Dam during 2014.

Table 7. Summary of collection entrances where tagged fish were initially detected and total number of collection entrances where tagged fish were detected during the study....

Table 8. Summary of fates of tagged juvenile Chinook salmon released upstream of Cowlitz Falls Dam during 2014

\section{Conversion Factors}

SI to Inch/Pound

\begin{tabular}{lll}
\hline \multicolumn{1}{c}{ Multiply } & \multicolumn{1}{c}{ By } & \multicolumn{1}{c}{ To obtain } \\
\hline & \multicolumn{1}{c}{ Length } & \\
\hline millimeter $(\mathrm{mm})$ & 0.03937 & inch (in.) \\
meter $(\mathrm{m})$ & 3.281 & foot $(\mathrm{ft})$ \\
\hline \multicolumn{3}{c}{ Flow rate } \\
\hline meter per second $(\mathrm{m} / \mathrm{s})$ & 3.281 & foot per second $(\mathrm{ft} / \mathrm{s})$ \\
\hline \multicolumn{2}{c}{ Mass } & \\
\hline gram $(\mathrm{g})$ & 0.03527 & ounce, avoirdupois $(\mathrm{oz})$ \\
\hline
\end{tabular}

Inch-pound to SI

\begin{tabular}{ccc}
\hline Multiply & By & To obtain \\
\hline & Flow rate & \\
\hline cubic foot per second $\left(\mathrm{ft}^{3} / \mathrm{s}\right)$ & 3.281 & foot per second $(\mathrm{ft} / \mathrm{s})$ \\
\hline
\end{tabular}

Temperature in degrees Celsius $\left({ }^{\circ} \mathrm{C}\right)$ may be converted to degrees Fahrenheit $\left({ }^{\circ} \mathrm{F}\right)$ as ${ }^{\circ} \mathrm{F}=\left(1.8 \times{ }^{\circ} \mathrm{C}\right)+32$. 


\title{
Evaluation of Two Juvenile Salmon Collection Devices at Cowlitz Falls Dam, Washington, 2014
}

\author{
By Tobias J. Kock, Theresa L. Liedtke, Brian K. Ekstrom, and William R. Hurst
}

\section{Executive Summary}

Collection of juvenile salmon at Cowlitz Falls Dam is a critical part of the effort to restore salmon in the upper Cowlitz River, Washington. Many of the fish that are not collected pass downstream and enter Riffe Lake, become landlocked, and are lost to the anadromous population. In addition to this loss, the juvenile fish collection system at Cowlitz Falls Dam, which originally consisted of four collection flumes, has failed to achieve annual collection goals since it began operating in 1996. In the years since, the collection flumes have been modified and prototype collection devices have been developed and tested, but these efforts have not substantially increased juvenile fish collection. Studies have shown that juvenile steelhead (Oncorhynchus mykiss), coho salmon (Oncorhynchus kisutch), and Chinook salmon (Oncorhynchus tshawytscha) tend to come close to the entrances of the collection system, but many of these fish fail to enter and eventually pass the dam through turbines or spillways.

Tacoma Power developed a prototype weir box in 2009 to increase capture rates of juvenile salmon at the collection entrances. The device was evaluated with radio-tagged coho salmon ( 318 fish) and Chinook salmon (317 fish), and was found to have a high retention rate; 93 percent of the coho salmon, and 91 percent of the Chinook salmon that entered the device were retained and collected. However, because of safety concerns at the dam, the weir box could not be deployed near a spillway gate where the prototype was tested, so the device was altered and re-deployed at a different location where it was evaluated during 2013. During that year, discovery efficiency (number of fish detected at the entrance divided by the number of fish detected in the forebay) was 98 percent for tagged steelhead and 83 percent for tagged coho salmon. However, none of the steelhead and only 5 percent of the coho salmon entered and were collected through the weir box. These results indicated that the device was not a promising collection alternative during spring months when steelhead and coho salmon are passing the dam. However, collection conditions change during summer months when juvenile Chinook salmon are passing, so the device also was evaluated during summer 2014.

In an attempt to improve overall collection efficiency, Tacoma Power developed and tested a new device in 2014, called the Upper Riffe Lake Collector (URLC). The URLC was a floating device designed to collect fish as they moved downstream after passing through turbines at Cowlitz Falls Dam. The design of the URLC included a pontoon barge that supported a large net structure designed to funnel fish into a live box where they could be removed and transported downstream of dams on the Cowlitz River.

During summer 2014, we evaluated the weir box and the URLC to determine the efficacy of using these devices to collect juvenile Chinook salmon at Cowlitz Falls Dam. The weir box was operated as one of four possible collection entrances at the face of the dam because flumes 1,2, and 4 also were operated during the study. To evaluate the effectiveness of the structures, we surgically implanted radio transmitters into 87 juvenile Chinook salmon and released them 3.9 river kilometers 
(rkm) upstream of Cowlitz Falls Dam. Additionally, 334 juvenile Chinook salmon were tagged and released 1.2 rkm upstream of Cowlitz Falls Dam as part of another study, and these fish also were monitored for this evaluation. This resulted in a total sample size of 421 fish for the study. We compared fish size, reservoir travel time, forebay residence time, and the horizontal and vertical distribution of tagged fish when they arrived at the dam to determine if there were significant release site effects. We determined that fish size and reservoir travel times were different between groups, but all other factors were similar, so data were pooled for most of the analyses.

A total of 363 tagged Chinook salmon arrived in the forebay of Cowlitz Falls Dam during the study period; 86 percent (311 fish) of the fish were detected on underwater antennas located along the face of the dam. Fish were horizontally distributed across the dam face when they arrived, but the lowest percentage of fish was first detected in the shallow zones of spillbays 2 and 3, where the collection entrances were located. The vertical distribution of tagged fish was skewed toward deeper zones (3.6 meters or deeper). Eighty percent of the tagged fish were first detected on zones located deeper than the entrances to the collection structures. This pattern of deep arrival appeared to affect collection and passage at the dam. The combined discovery efficiency of all surface collection entrances was only 43 percent, and the number of fish that passed the dam through turbines (230 fish) was nearly five times greater than the number of fish that were collected (50 fish). Collection peaked during morning hours and turbine passage peaked during nighttime hours.

The weir box was the most successful collection route for juvenile Chinook salmon in our study. A total of 157 tagged fish were detected near collection entrances, and 91 percent (143 fish) of these fish were first detected at the weir box. Fifty-two percent of the tagged fish (81 fish) that arrived at collection entrances were only detected at the weir box. Discovery efficiency of the weir box (76 percent) was greater than discovery efficiency of flumes 1 and 2 ( 35 percent). These data show that the weir box outperformed the other collection entrances, but the effects of dam operations on this performance also should be considered. Turbine unit 2, which is located beneath the weir box, was operated during 90 percent of the study period, whereas unit 1, which is located beneath flumes 1 and 2 , was only operated during 3 percent of the study period. It is generally accepted that turbine flow is an important guidance mechanism for juvenile salmon at Cowlitz Falls Dam, so the effects of dam operations on the study results must be considered. Additionally, entrance efficiency ( 52 percent) and retention efficiency ( 24 percent) of the weir box were relatively low and limited the overall success of the device. Overall, fish collection efficiency was 12 percent during 2014 and was composed of collection through the weir box ( 5 percent), flumes 1 and 2 ( 4 percent), flume 4 ( 2 percent), and unassigned routes ( 1 percent). The tendency for juvenile Chinook salmon to migrate in deep water may limit improvements to discovery metrics of surface collection routes unless other devices such as guide nets, or alterations to the debris barrier, are used in the future. However, improvements to entrance and retention characteristics of the weir box may be feasible by altering factors such as flow and weir height.

Although a large number of tagged fish (230 fish) passed through turbines and entered the tailrace of Cowlitz Falls Dam, few fish (24 fish; 10 percent) entered the discovery zone (within 6.1 meters of the entrance) of the URLC. The tailrace of Cowlitz Falls Dam is fairly constrained, which limits egress routes for juvenile salmon. However, little is known about the horizontal and vertical distribution of juvenile salmon as they move downstream through the tailrace. Median residence in the reach located $0.5 \mathrm{rkm}$ downstream of the dam was 0.37 hours ( 22.7 minutes), and 90 percent of the tagged fish exited the reach within 1.5 hours of passing the dam. This suggests that fish moved fairly quickly past the URLC, and indicates the need to know exactly where fish are moving in the tailrace to optimize the placement of the URLC and to maximize the number of fish that discover the entrance to the device. 


\section{Introduction}

Surface collection systems can increase survival for juvenile salmon at dams, but to be effective they must collect a large proportion of the population because fish that are not collected will pass through other routes where injury or death can occur. Most dams provide multiple passage routes (for example, collection systems, turbines, spillways) for juvenile fish migrating downstream. Juvenile salmon rely on factors such as water velocity and turbulence to guide their downstream movements, so routes that pass large volumes of water are highly effective at passing fish (Coutant, 2001; Tiffan and others, 2009). Surface collection systems are effective because juvenile salmon typically migrate near the surface, but these systems must create conditions in a dam forebay that are conducive to discovery, entry, and retention (Coutant and Whitney, 2000; Adams and others, 2001; Johnson and Dauble, 2006; Evans and others, 2008). Otherwise, the risk of passing through alternate routes is greatly increased.

The surface collection system at Cowlitz Falls Dam, located on the upper Cowlitz River, Washington (fig. 1), is known to attract juvenile salmon effectively in a variety of configurations. The collection system was originally designed and operated with four collection flumes that are located inside spillbays 2 and 3 (fig. 2). The two turbine units at the dam are located beneath these spillbays, so water that passes through the turbines guides fish toward the center of the dam where the collection flumes are located. However, a floating debris barrier is located upstream of spillbays 2 and 3 , and this device extends $2.7 \mathrm{~m}$ below the water surface (fig. 2). Thus, fish must sound underneath the debris barrier before they can approach the surface collection flumes. Many of the fish that are attracted to the collection entrances fail to enter the system, and this factor is largely responsible for the failure of the system to meet annual collection goals. Juvenile salmon that arrive at Cowlitz Falls Dam either are collected or they pass the dam and enter Riffe Lake. Fish that are collected are transported by truck around the other dams in the Cowlitz River hydrosystem and released into stress-relief ponds from which they can volitionally outmigrate into the free-flowing river. With the exception of fish that are collected through supplemental methods (seining and Fyke-netting), fish that enter Riffe Lake become landlocked and, therefore, do not contribute to the anadromous fish population. Studies have shown that discovery rates of the surface collection system routinely exceed 90 percent at Cowlitz Falls Dam (Hausmann and others, 2001; Farley and others, 2003; Liedtke and others, 2009). However, results from mark-recapture studies indicate that only about 46 percent of juvenile steelhead (Oncorhynchus mykiss), 30 percent of juvenile coho salmon (Oncorhynchus kisutch), and 21 percent of juvenile Chinook salmon (Oncorhynchus tshawytscha) were collected annually during 1996-2013 (Serl and Heimbigner, 2014). In 2003, Perry and others (2004) used radiotelemetry and an acoustic camera to monitor fish behavior within $1 \mathrm{~m}$ of the collection flume entrances at Cowlitz Falls Dam. They reported that "at most only 25 percent of the fish that come within $1 \mathrm{~m}$ of the flume entrances subsequently pass into the entrance" (Perry and others, 2004; page 54). These studies show that discovery rates are sufficient to result in high collection rates, but entry and retention issues have limited collection success. 

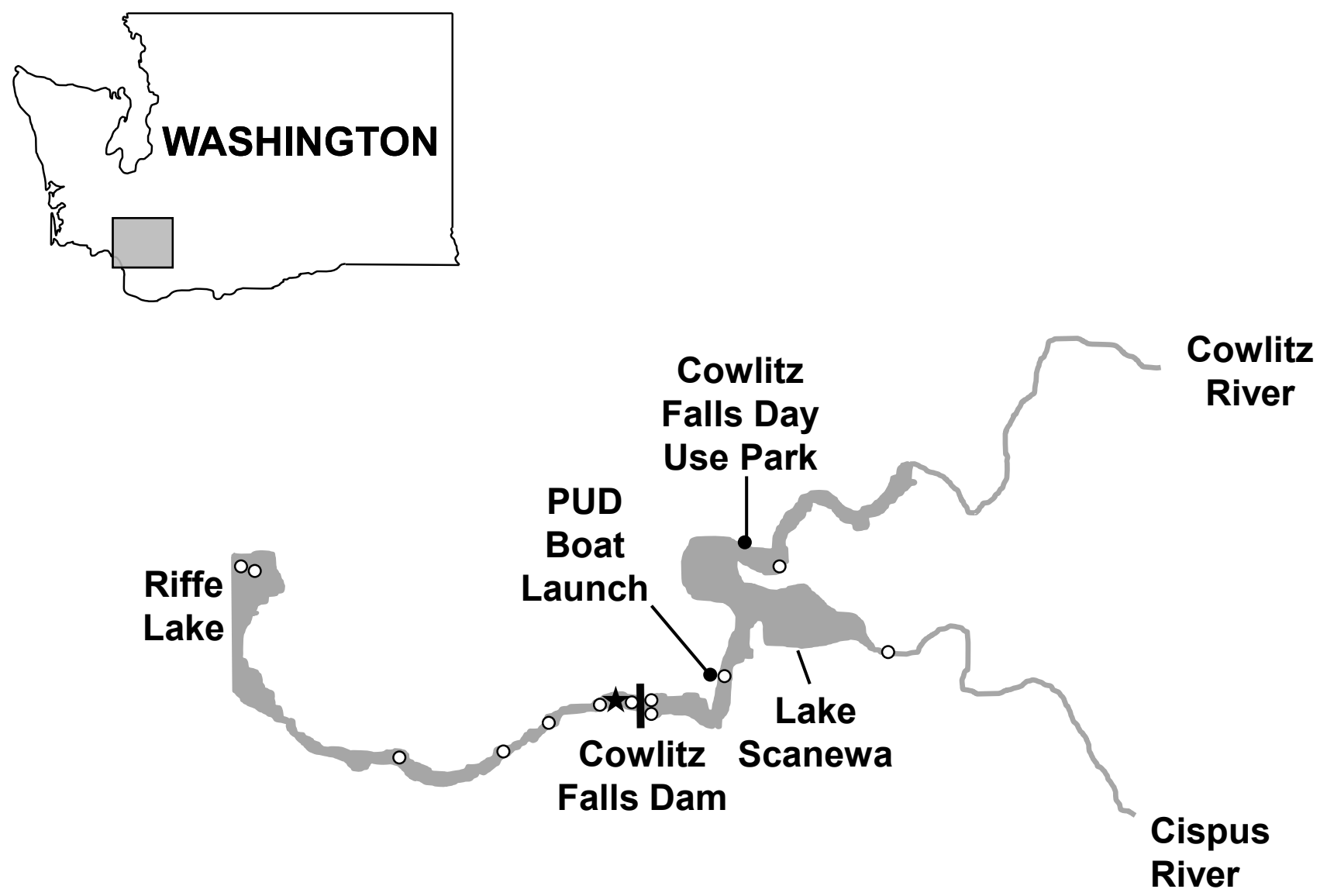

Figure 1. Schematic of the study area showing locations of fixed monitoring sites (open circles), release sites (filled circles), and the Upper Riffe Lake Collector (star), Washington. 


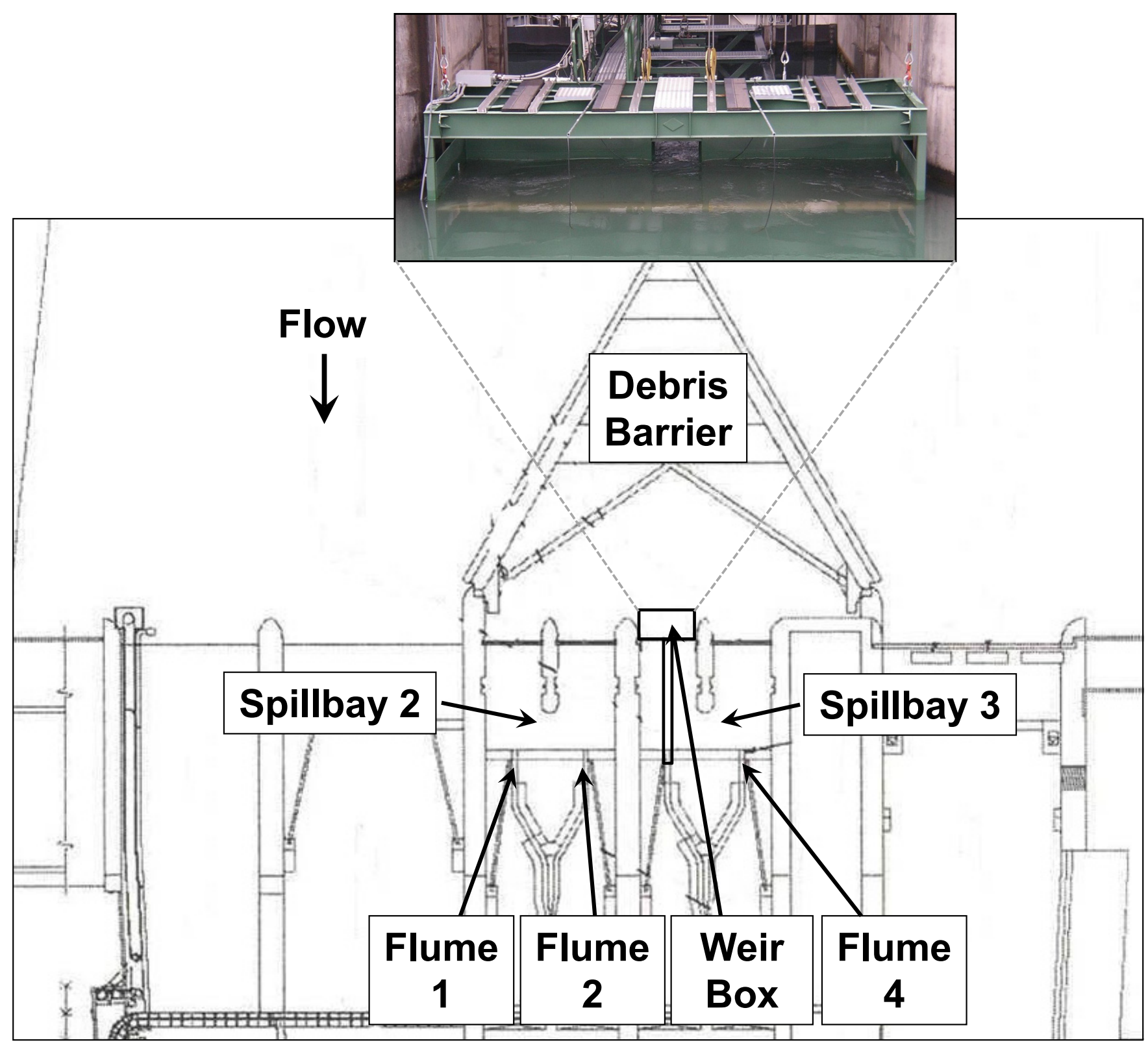

Figure 2. Schematic of Cowlitz Falls Dam showing locations of the debris barrier and spillbays 2 and 3, where juvenile salmon collection occurred through flume 1, flume 2, the weir box, and flume 4 . Photograph of the weir box also is shown. 
Tacoma Power developed and tested two prototype fish collection devices at Cowlitz Falls Dam during 2006-2010 in an attempt to improve annual fish collection efficiencies. The first device was a fish screen that was $12.2 \mathrm{~m}$ long and was deployed inside spillbay 3 as a single collection entrance (Kock and others, 2007). The fish screen had a 6.1-m wide by 6.1-m deep entrance and the device gradually narrowed in the downstream direction to provide uniform water acceleration $(0-2.1 \mathrm{~m} / \mathrm{s})$, which has been shown to be an important factor in optimizing surface collection of juvenile fish (Haro and others, 1998). The second device was a weir box that was designed as a wide $(8.5 \mathrm{~m})$, shallow (0.6 $\mathrm{m})$ structure that attached at the upstream entrance to collection flumes 1 and 2, inside spillbay 2 (Liedtke and others, 2010). The weir box created a wide, shallow flow field that spilled over the weir crest and captured smolts in a high flow, turbulent holding box where they were susceptible to entrainment in collection flumes. In 2009, the fish screen and weir box were evaluated simultaneously during a radiotelemetry evaluation in which 318 juvenile coho salmon and 317 juvenile Chinook salmon were monitored. The discovery efficiency (number of tagged fish detected within $6.1 \mathrm{~m}$ of the entrance divided by the number of tagged fish detected in the forebay) of the fish screen and weir box was similar for juvenile coho salmon (about 80 percent for each device) and Chinook salmon (about 60 percent for each device), but capture efficiencies (number of tagged fish collected divided by the number of tagged fish detected within $6.1 \mathrm{~m}$ of the entrance) were substantially greater for the weir box (Liedtke and others, 2010). For coho salmon, the capture efficiency of the weir box was 93 percent, whereas the capture efficiency of the fish screen was 16 percent (Liedtke and others, 2010). This relationship was similar for Chinook salmon, as capture efficiencies of the weir box were 91 percent compared to 38 percent for the fish screen (Liedtke and others, 2010). Given these findings, the weir box appeared to be a promising option for improving capture efficiencies, and thereby increasing fish collection at Cowlitz Falls Dam.

In 2013, Tacoma Power developed a plan to install and evaluate a weir box during the peak outmigration period for juvenile steelhead and coho salmon at Cowlitz Falls Dam. The proposed location and size of the weir box differed from the initial test of the device during 2009 because of dam safety concerns that prevented it from being deployed in the location where it was originally tested. The 2013 weir box was only $6.1 \mathrm{~m}$ wide and was located at baffle panel 3, which was upstream of the location where the 2009 weir box was deployed (flumes 2 and 3; fig. 2). We conducted an assessment of the 2013 weir box by tagging, releasing, and monitoring the movements of 45 juvenile steelhead and 45 juvenile coho salmon (Kock and others, 2014). In total, 29 tagged steelhead and 36 tagged coho salmon were collected during the study, but nearly all these fish (all steelhead and 95 percent of coho salmon) were collected through flumes 1 and 2, rather than through the weir box (Kock and others, 2014). These results indicated that the 2013 weir box was not likely to result in substantial collection of juvenile steelhead and coho salmon at Cowlitz Falls Dam. 
Although the 2013 weir box performed poorly for collecting juvenile steelhead and coho salmon, it was not tested during the summer months when juvenile Chinook salmon are passing the dam. Collection conditions at Cowlitz Falls Dam change substantially between spring and summer months. Water temperatures during the spring generally range from 5 to $10{ }^{\circ} \mathrm{C}$, whereas summer water temperatures often exceed $17^{\circ} \mathrm{C}$. River flows in the 5,000-12,000 $\mathrm{ft}^{3} / \mathrm{s}$ range are common during the spring, so both turbine units are typically operated during this period and spill operations are often required. During the summer, river flows decrease to less than $1,500 \mathrm{ft}^{3} / \mathrm{s}$ and a single turbine unit is often operated intermittently. The composition of the outmigrant population changes as well. Steelhead and coho salmon are the predominant species that pass during spring months, and juvenile Chinook salmon primarily pass during summer months. Given these differences, evaluation of the weir box during summer months was important for assessing the future of the device at Cowlitz Falls Dam. This assessment was conducted during 2014, in conjunction with an evaluation of a new collection device that was located downstream of Cowlitz Falls Dam.

Tacoma Power developed a floating collection device, known as the Upper Riffe Lake Collector (URLC), which was designed to capture juvenile salmon in the tailrace of Cowlitz Falls Dam during 2014. The URLC was deployed $0.17 \mathrm{rkm}$ downstream of the dam and consisted of three parts: a pontoon barge, a net structure, and a live box (fig. 3 ). The pontoon barge $(9.1 \mathrm{~m}$ long; $4.8 \mathrm{~m}$ wide) was the primary support structure for the URLC. It provided floatation for the net structure and served as a work platform for staff when fish were being removed from the live box at the downstream end of the structure. The net structure was $16.2 \mathrm{~m}$ long and oriented into the current. It had a large opening $(3.0 \mathrm{~m}$ wide; $2.4 \mathrm{~m}$ deep) at the upstream end and attached to the live box at the downstream end (fig. 3 ). The net structure gradually narrowed along its length to funnel fish into the live box, where they could be removed for transportation. The entrance to the live box included a Fyke-style opening that was designed to retain fish. The URLC was deployed in the tailrace of Cowlitz Falls Dam from July 31, 2014, to September 15, 2014. Tacoma Power staff members visited the trap 5 days per week to remove fish that were caught.

We used radiotelemetry to evaluate concurrently the weir box and URLC during 2014. Tacoma Power purchased 90 radio transmitters for these evaluations. A concurrent study designed to evaluate dam passage survival of juvenile Chinook salmon at Cowlitz Falls Dam for the Lewis County Public Utility District (PUD) included the tagging and release of an additional 334 juvenile Chinook salmon upstream of the dam. We recognized the efficiency of pooling detections of tagged fish from both the Tacoma Power and Lewis County PUD studies in our assessment of the weir box and URLC, so we coordinated transmitter specifications to insure that fish from both studies could be monitored simultaneously. Our objectives were to determine discovery efficiency, entrance efficiency, retention efficiency, and capture efficiency for the weir box and URLC. 

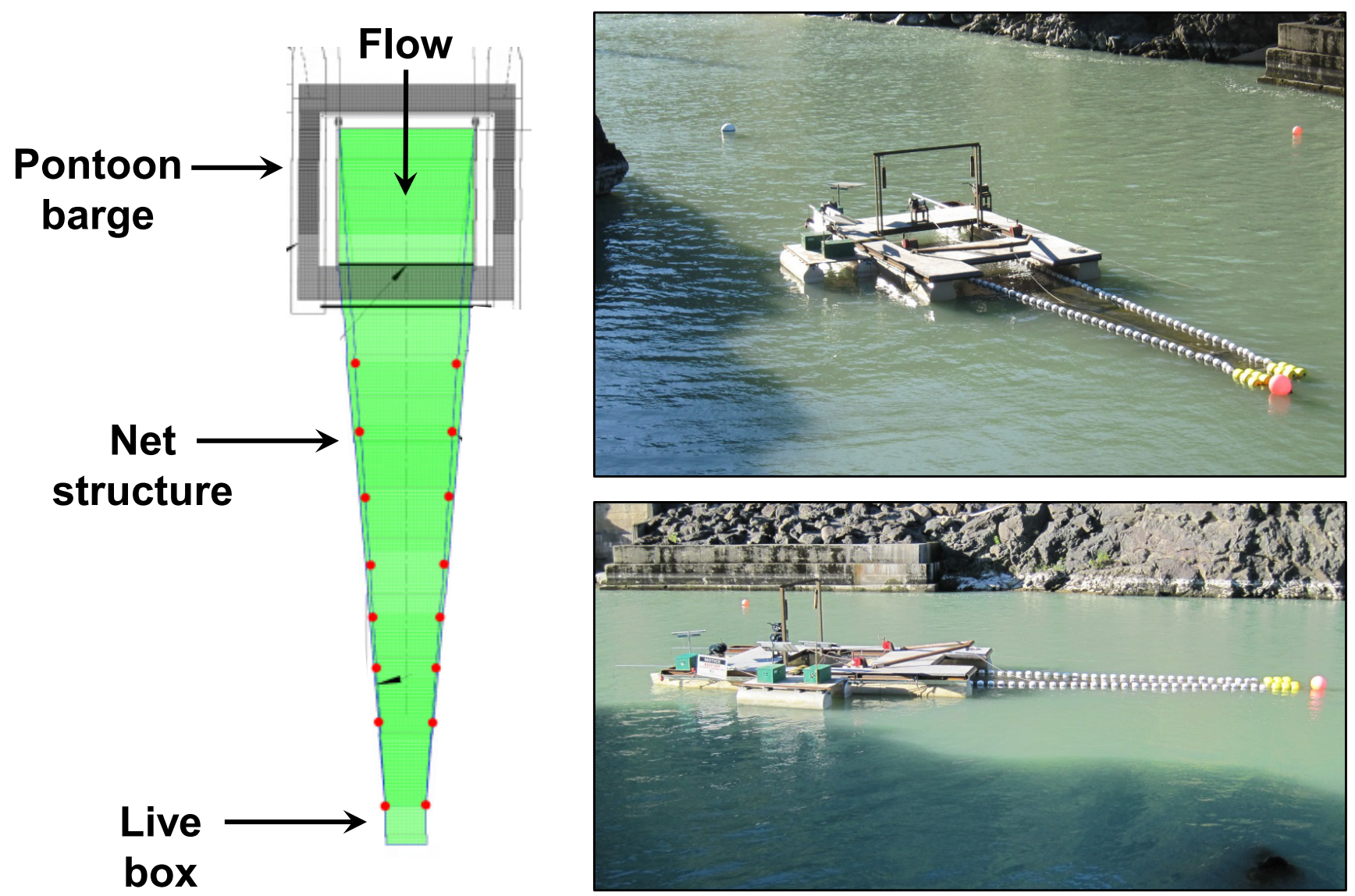

Figure 3. Schematic and photographs of the Upper Riffe Lake Collector deployed in the tailrace of Cowlitz Falls Dam during 2014. 


\section{Methods}

\section{Fish Collection, Tagging, and Release}

Juvenile Chinook salmon were collected and tagged at the Cowlitz Falls Dam fish facility during July-August 2014. A total of 87 juvenile Chinook salmon (table 1) were double-tagged with a radio transmitter (Model NTQ-2; Lotek ${ }^{\circledR}$ Wireless Inc., Newmarket, Ontario, Canada) and a passive integrated transponder (PIT) tag (Model HPT12 12.5 mm 134.2 kHz ISO FDXB; Biomark ${ }^{\circledR}$, Inc., Boise, Idaho). Each radio transmitter weighed $0.30 \mathrm{~g}$ (in air) and had an expected operating life of $23 \mathrm{~d}$. Transmitters and PIT tags were surgically implanted into the body cavity of study fish using methods described in Liedtke and others (2012). Following tagging, fish were held at the Cowlitz Falls fish facility for about $24 \mathrm{~h}$ to allow for recovery and to monitor short-term mortality that could result from the handling and tagging process. Fish were then transported by automobile to the Cowlitz Falls Day Use Park (3.9 rkm upstream of the dam; fig. 1) and released. An evaluation of passage survival of juvenile Chinook salmon at Cowlitz Falls Dam was conducted concurrently with the weir box and URLC study during 2014. For that study, 334 juvenile Chinook salmon were radio-tagged and released upstream of Cowlitz Falls Dam (table 1). The transmitters that were used for this study were the same model as those previously described, so we were able to monitor movements of tagged fish from both studies as we evaluated the weir box and URLC. This resulted in a total of 421 radio-tagged fish being released upstream of Cowlitz Falls Dam during July-August 2014 (table 1). There were two differences between fish used in the two studies. The 87 fish used in the Tacoma Power study were double-tagged (radio transmitter and PIT tag) and released at the Cowlitz Falls Day Use Park, and the 334 fish used in the Lewis County PUD study were only tagged with a radio transmitter and were released at the PUD Boat Launch (1.2 rkm upstream of the dam). For both studies, the same taggers and standard operating procedures were used for tagging, handling, and transporting, so we did not anticipate significant differences between the release groups, apart from the release location. 
Table 1. Summary of release dates, number of fish released, and average sizes of juvenile Chinook salmon released during a radiotelemetry evaluation at Cowlitz Falls Dam, Washington, 2014.

[Weight and Fork length: Numbers in parentheses are one standard deviation from the mean. Abbreviations: g, gram; mm, millimeter; PUD, Public Utility District]

\begin{tabular}{llccc}
\hline \multicolumn{1}{c}{ Release date } & \multicolumn{1}{c}{ Release site } & $\begin{array}{c}\text { Number of fish } \\
\text { released }\end{array}$ & Weight (g) & Fork length (mm) \\
\hline $7 / 31 / 2014$ & Day Use Park & 20 & $12.0(2.3)$ & $103.9(6.5)$ \\
$8 / 07 / 2014$ & Day Use Park & 23 & $12.1(2.3)$ & $103.6(6.8)$ \\
$8 / 12 / 2014$ & Day Use Park & 24 & $11.8(1.5)$ & $102.4(3.8)$ \\
$8 / 15 / 2014$ & Day Use Park & 20 & $12.9(2.9)$ & $105.8(7.6)$ \\
& & 87 & $12.2(2.3)$ & $103.9(6.3)$ \\
$7 / 16 / 2014$ & Total & 23 & $18.4(4.1)$ & $117.9(8.9)$ \\
$7 / 17 / 2014$ & PUD Boat Launch & 32 & $20.8(4.6)$ & $121.7(8.0)$ \\
$7 / 22 / 2014$ & PUD Boat Launch & 30 & $18.3(4.7)$ & $117.4(10.7)$ \\
$7 / 23 / 2014$ & PUD Boat Launch & 29 & $18.6(3.4)$ & $117.8(7.8)$ \\
$7 / 29 / 2014$ & PUD Boat Launch & 28 & $15.1(3.9)$ & $116.8(30.8)$ \\
$7 / 30 / 2014$ & PUD Boat Launch & 28 & $14.5(2.7)$ & $109.5(6.8)$ \\
$8 / 06 / 2014$ & PUD Boat Launch & 8 & $12.6(2.4)$ & $104.9(7.3)$ \\
$8 / 07 / 2014$ & PUD Boat Launch & 26 & $11.7(1.9)$ & $103.5(6.2)$ \\
$8 / 08 / 2014$ & PUD Boat Launch & 50 & $11.6(1.9)$ & $101.9(5.5)$ \\
$8 / 12 / 2014$ & PUD Boat Launch & 28 & $12.4(1.7)$ & $103.6(4.7)$ \\
$8 / 13 / 2014$ & PUD Boat Launch & 28 & $11.8(1.7)$ & $102.5(4.9)$ \\
$8 / 14 / 2014$ & PUD Boat Launch & 24 & $10.9(1.3)$ & $100.2(4.1)$ \\
& PUD Boat Launch & 334 & $14.8(4.5)$ & $109.4(10.3)$ \\
& Total & & $14.2(4.3)$ & $108.2(9.8)$ \\
\hline
\end{tabular}

\section{Configuration of the Fish Collection System at Cowlitz Falls Dam}

The Cowlitz Falls Dam fish collection system was operated with three primary collection entrances during July-August 2014. The primary collection entrances included flumes 1 and 2 and the weir box (fig. 2). Flumes 1 and 2 were located inside spillbay 2, and the weir box was located at the north, upstream entrance into spillbay 3 (fig. 2). The weir box collected fish immediately upstream of spillbay 3 and the remaining upstream entrances into the spillbay were completely blocked by baffle panels (fig. 4). However, induction slot entrances into spillbay 3 remained open so it was possible for fish to enter spillbay 3 and be collected through flume 4 (fig. 4). We documented fish collection through flume 4 in 2007 and 2008, when the dam was configured in a similar fashion (Liedtke and others, 2007, 2009). Given this possibility, fish collection through flume 4 was possible, but was considered to be a secondary collection entrance given that low numbers of fish would be expected to enter spillbay 3 through the induction slots. 


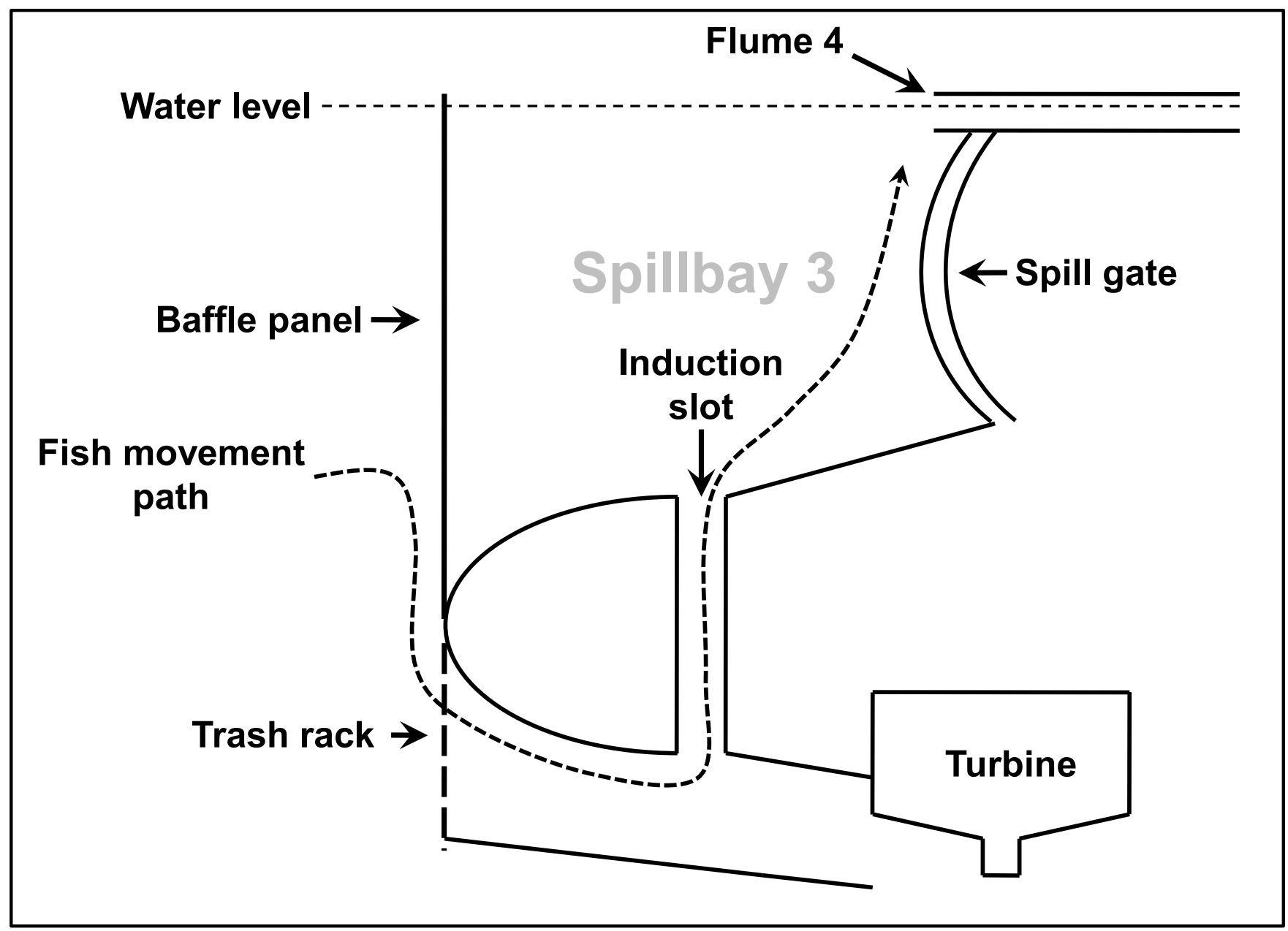

Figure 4. Schematic of the side view of spillbay 3 at Cowlitz Falls Dam showing the path of movement that juvenile Chinook salmon would have to take to be collected in flume 4 during July-August 2014.

\section{Monitoring Array}

We used aerial and underwater monitoring systems to detect tagged fish during the study. Twelve aerial fixed monitoring sites (hereafter referred to as "fixed sites") were operated within the study area to monitor general movement patterns of tagged fish (fig. 1). Three fixed sites were located in Lake Scanewa to monitor movement patterns in the reservoir and detected fish in the Cowlitz Arm of Lake Scanewa, in the Cispus Arm of Lake Scanewa, and near the PUD Boat Launch (fig. 1). Two fixed sites were located on Cowlitz Falls Dam to monitor fish as they approached the dam. The remaining fixed sites were located downstream of the dam. These sites were primarily used to collect data for the Lewis County PUD study, but the PUD allowed us to collect additional data near the URLC and were useful for confirming dam passage of individual fish. These sites were located $0.05,0.5,2.0,3.5,4.7$, and $7.0 \mathrm{rkm}$ (two sites) downstream of the dam. 
Sixty-five underwater antennas were used to monitor fine-scale movements of tagged fish at Cowlitz Falls Dam. The antenna locations were selected to optimize data collection as tagged fish approached the dam, discovered the entrances to the collection devices, and entered the fish collection system. All the underwater antennas at the dam were monitored by a Multiprotocol Integrated Telemetry Acquisition System (MITAS; SigmaEight, Inc., Newmarket, Ontario, Canada). Detection data from the MITAS were grouped during analysis to create a series of detection zones to describe near-dam fish behavior. In the event that a tagged fish was simultaneously detected in more than one zone, the fish was assigned to the zone that had the highest signal strength of detection.

The first series of antennas that tagged fish encountered as they approached the forebay were located along the face of the dam (fig. 5). Antenna locations were selected to describe horizontal and depth distributions of tagged fish as they arrived at the dam. Horizontal distributions were determined by grouping detections from antennas within each spillbay, which created arrival zones for spillbays 1 , 2, 3, and 4 (fig. 5). Depth distributions were determined by grouping detections from antennas that were located at five depths across the dam face: 0.9, 3.6, 7.9 14.9 and $25.6 \mathrm{~m}$ (fig. 5). Fish collection entrances were located at the surface, so antennas were grouped into two depth zones, referred to as "shallow" and "deep". The purpose of the two depth zones was to determine if fish arrived at the dam near the surface, where they could encounter collection entrances, or if they arrived at the dam deeper than where collection entrances were located. The shallow zone included antennas located $0.9 \mathrm{~m}$ below the surface, and the deep zone included antennas located 3.6, 7.9, 14.9 and $25.6 \mathrm{~m}$ below the surface (fig. 5).

The second series of antennas were located near the collection entrances and inside the collection flumes to detect fish when they encountered a collection entrance, and to identify collection routes for fish that were collected. Single antennas were located at the entrances to flumes 1, 2 and 4 and detected fish within $6.1 \mathrm{~m}$ of these locations. Two antennas were located at the weir box entrance and detected fish within $6.1 \mathrm{~m}$ of that entrance. Two more antennas were located inside the weir box and detected fish that entered the device. Three antennas were located inside each collection flume, and downstream of entrances to flumes 1 and 2, the weir box, and flume 4 . These antennas detected fish that were collected through each route. Additional antennas also were located in the fish transport flume, between the collection flumes and in the fish collection facility. These antennas detected fish as they were moved downstream to the collection facility to confirm when collection occurred. 


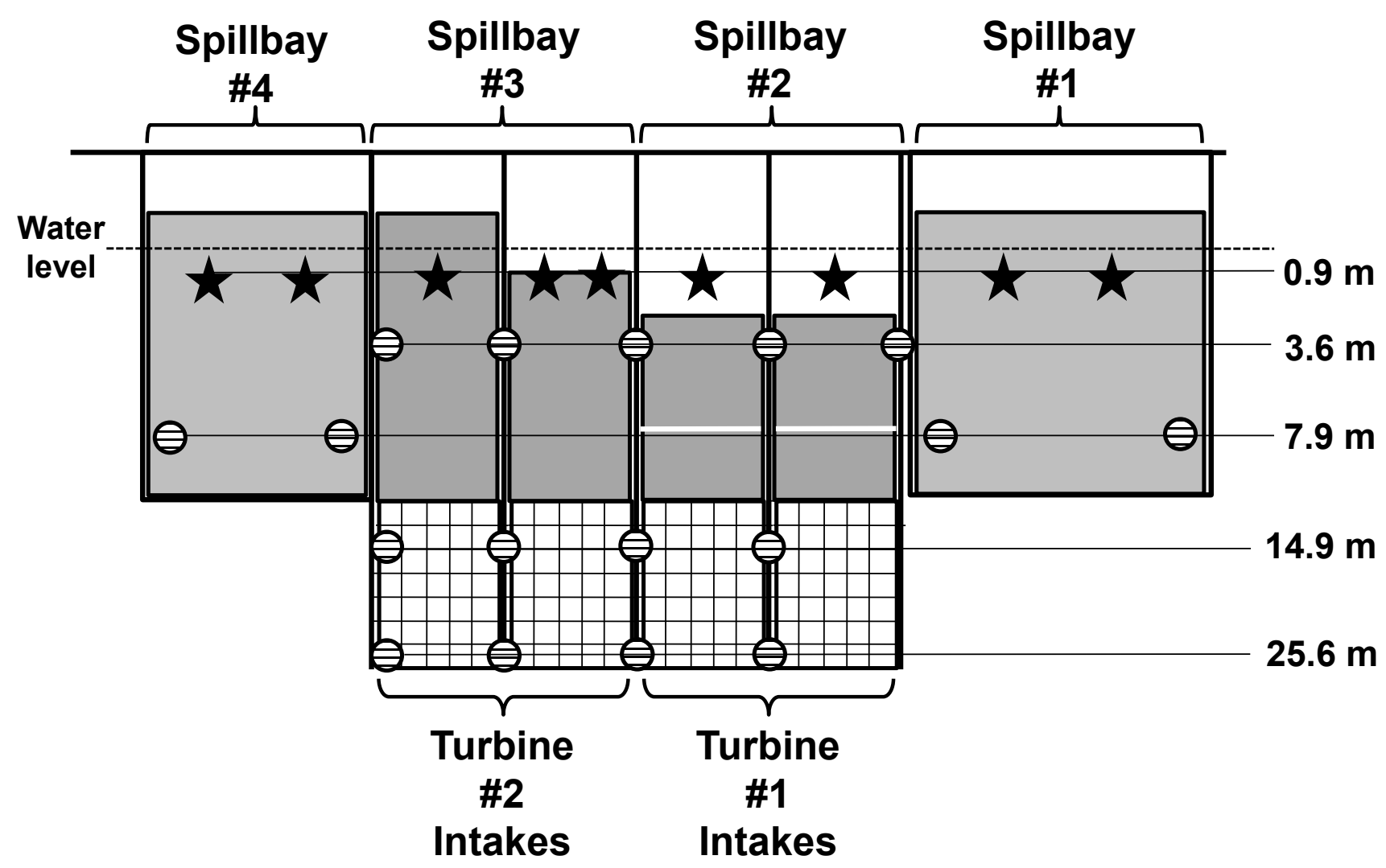

Figure 5. Schematic of Cowlitz Falls Dam and location of general detection zones for an underwater antenna detection array that monitored radio-tagged juvenile Chinook salmon during July-August 2014. Stars identify locations of shallow underwater antennas and circles identify locations of deep underwater antennas. 
Two aerial fixed sites and three underwater antenna arrays were used to monitor fish movements near the URLC. Fish entered the study area for the URLC when they passed Cowlitz Falls Dam and were detected on the upstream fixed site, located $0.05 \mathrm{rkm}$ downstream of the dam. Fish exited the URLC study area when they moved downstream of the device and were detected on the downstream fixed site, located $0.5 \mathrm{rkm}$ downstream of the dam. Underwater antennas were placed upstream of, and inside the URLC to detect fish as they discovered, entered, and were collected by the URLC. Two antennas were located at the URLC entrance and detected fish within $6.1 \mathrm{~m}$ of the entrance. Four antennas were located inside the URLC, along the length of the net structure, to detect fish that entered the device. Two antennas were located inside the live box and detected fish that were retained in the device. The detection range of the antennas inside the net structure and live box was attenuated to insure that tagged fish were only detected when they were inside the URLC.

\section{Data Analysis}

\section{Assessment of Differences between Release Sites}

We compared fish size, reservoir travel time, forebay residence time, and the horizontal and vertical distribution of tagged fish when they arrived at the dam to assess differences between groups of fish that were released at the Day Use Park and the PUD Boat Launch. Fish size was compared using data on fork length (in millimeters) and fish weight (in grams). Fish-size data were pooled across the tagging period by release site and differences were assessed using a t-test (Sokal and Rohlf, 1994). Releases at the PUD Boat Launch occurred across a greater temporal period of the study than releases at the Day Use Park, so we also assessed fish size during the period when both groups of fish were being released. Reservoir travel time was obtained for each fish that arrived in the forebay of Cowlitz Falls Dam by subtracting the date and time of release from the first date and time of forebay detection. Forebay residence time was calculated as the elapsed time between the first and last detection in the forebay. Event-time analysis (Allison, 2008) was used to compare reservoir travel time and forebay residence time between release groups. Forebay arrival was the event of interest when comparing reservoir travel time, and last detection in the forebay was the event of interest when comparing forebay residence time. For each comparison, Kaplan-Meier plots were created to display travel time and residence time distributions for groups of fish from the two release sites. The Log-Rank statistic was used to test for significant differences between groups (Allison, 2008), and statistical significance was determined when $p$ was less than 0.05. Each tagged fish that arrived at Cowlitz Falls Dam was assigned to one of four horizontal arrival zones (spillbays 1,2,3, or 4) and to one of two depth arrival zones (shallow, or deep), based on the first detection event on underwater antennas located along the face of the dam. The distribution of horizontal and depth arrival zones was compared between release sites using Fisher's exact test. 


\section{Behavior Patterns, Performance Metrics, and Dam Passage}

Arrival patterns were pooled among release sites and assigned to one of three arrival periods to determine if arrival patterns differed temporally. The three arrival periods included July 16-July 29, 2014, July 30-August 12, 2014, and August 13-August 26, 2014. The distribution of horizontal and depth arrival zones were compared between arrival periods using Fisher's exact test.

A series of performance metrics were used to assess fish movement patterns and collector performance in the dam forebay (table 2). The performance metrics were developed to describe movement patterns of fish from forebay arrival to the point when they were collected or rejected collection through the various collection routes. Collection entrances were located near the surface, in spillbays 2 and 3, but this area was blocked by the debris barrier so fish had to sound beneath the debris barrier and then move back to the surface to locate collection entrances. The first metric, debris barrier discovery efficiency, described the percentage of fish that were detected inside the debris barrier area, near spillbays 2 and 3 (fig. 2). Tagged fish that arrived in this location could be detected on underwater antennas that were located 0.9 or $3.6 \mathrm{~m}$ below the water surface (fig. 5). The remaining metrics described the percentage of fish that discovered, entered, and were retained in flume 1/flume 2 and the weir box. Descriptions of the calculations used for each metric are located in table 2. It was possible for tagged individuals to discover and enter multiple collection entrances without being collected during the study period. For this reason, tagged individuals could be enumerated in discovery and entrance metrics for each of the collection devices that were assessed. However, individual tagged fish could only be collected one time during the study and thus were enumerated a maximum of one time for the collection metrics. We also summarized collection and dam passage events during each hour of the day to evaluate diel patterns in collection and passage.

Detection events at antennas located at entrances to flume $1 /$ flume 2 , the weir box, and flume 4 were analyzed to describe discovery patterns by tagged fish. Discovery patterns were assessed for individual fish based on the collection entrance that was first encountered and the number of unique collection entrances that were encountered while the fish was in the dam forebay. Some tagged fish made repeated movements between collection entrances, so we also quantified the number of discovery events for individual fish at the collection entrances.

Dam passage and timing were quantified to describe the percentage of tagged fish that passed through various routes at the dam and to determine if diel patterns were present. Tagged fish could pass the dam through one of three collection routes (flume 1/flume 2, weir box, flume 4) or by passing through the turbines. The hour of collection was obtained from underwater antennas that were located inside collection flumes. The hour of turbine passage was obtained from the first detection event on the tailrace monitoring site that was located $0.05 \mathrm{rkm}$ downstream of the dam.

Performance metrics also were used to assess fish movement patterns and collector performance for the URLC. Calculations used for each of the URLC performance metrics are described in table 3. 
Table 2. Descriptions of performance metrics used to evaluate the collection flumes and weir box during 2014.

\begin{tabular}{|c|c|}
\hline Metric & Definition \\
\hline Debris barrier discovery efficiency & $\begin{array}{l}\text { Number of tagged fish detected inside the debris barrier area divided } \\
\text { by the number of tagged fish detected in the forebay of Cowlitz Falls } \\
\text { Dam. }\end{array}$ \\
\hline Flume discovery efficiency & $\begin{array}{l}\text { Number of tagged fish detected within } 6.1 \text { meters of flumes } 1 \text { and } 2 \\
\text { divided by the number of tagged fish detected inside the debris } \\
\text { barrier area. }\end{array}$ \\
\hline Flume entrance efficiency & $\begin{array}{l}\text { Number of tagged fish that entered collection flumes } 1 \text { and } 2 \text { divided } \\
\text { by the number of tagged fish detected within } 6.1 \text { meters of collection } \\
\text { flumes } 1 \text { and } 2 \text {. }\end{array}$ \\
\hline Flume retention efficiency & $\begin{array}{l}\text { Number of tagged fish collected through collection flumes } 1 \text { and } 2 \\
\text { divided by the number of tagged fish that entered collection flumes } 1 \\
\text { and } 2 \text {. }\end{array}$ \\
\hline Flume fish capture efficiency & $\begin{array}{l}\text { Number of tagged fish collected through the collection flumes divided } \\
\text { by the number of tagged fish detected in the forebay of Cowlitz Falls } \\
\text { Dam. }\end{array}$ \\
\hline Weir box discovery efficiency & $\begin{array}{l}\text { Number of tagged fish detected within } 6.1 \text { meters of the weir box } \\
\text { entrance divided by the number of tagged fish detected inside the } \\
\text { debris barrier area. }\end{array}$ \\
\hline Weir box entrance efficiency & $\begin{array}{l}\text { Number of tagged fish that entered the weir box divided by the number } \\
\text { of tagged fish detected within } 6.1 \text { meters of the weir box entrance. }\end{array}$ \\
\hline Weir box retention efficiency & $\begin{array}{l}\text { Number of tagged fish collected through the weir box divided by the } \\
\text { number of tagged fish that entered the weir box. }\end{array}$ \\
\hline Weir box fish capture efficiency & $\begin{array}{l}\text { Number of tagged fish collected through the weir box divided by the } \\
\text { number of tagged fish detected in the forebay of Cowlitz Falls Dam. }\end{array}$ \\
\hline
\end{tabular}

Table 3. Descriptions of performance metrics used to evaluate the Upper Riffe Lake Collector (URLC) during 2014.

\begin{tabular}{lc}
\hline \multicolumn{1}{c}{ Metric } & Definition \\
\hline URLC discovery efficiency & $\begin{array}{c}\text { Number of tagged fish detected within } 6.1 \text { meters of the URLC } \\
\text { entrance divided by the number of tagged fish detected in the tailrace } \\
\text { of Cowlitz Falls Dam. } \\
\text { Number of tagged fish detected inside the net structure divided by the } \\
\text { number of tagged fish detected within } 6.1 \text { meters of the URLC } \\
\text { entrance. } \\
\text { Number of tagged fish detected inside the net structure that remained in } \\
\text { the URLC divided by the total number of tagged fish detected inside } \\
\text { the net structure (includes fish that remained in the URLC and fish } \\
\text { that left the URLC). } \\
\text { Number of tagged fish detected inside the live box divided by the } \\
\text { number of tagged fish detected inside the net structure. } \\
\text { Number of tagged fish collected divided by the number of tagged fish } \\
\text { detected inside the live box. } \\
\text { Number of tagged fish collected in the URLC divided by the number of } \\
\text { tagged fish detected in the tailrace of Cowlitz Falls Dam. }\end{array}$ \\
Live box retention efficiency &
\end{tabular}




\section{Results}

\section{Assessment of Differences between Release Sites}

Most of the tagged fish that were used to evaluate the collection flumes, weir box and URLC were released at the PUD Boat Launch. A total of 421 tagged fish were released and monitored during the study period and most of the releases (79 percent; 334 fish) were made at the PUD Boat Launch (table 1). Tagged fish were released at the PUD Boat Launch from July 16 to August 14, 2014 and at the Day Use Park from July 31 to August 15, 2014 (table 1). The average size of tagged fish in daily release groups decreased during July and then stabilized during August (fig. 6). Tagged fish released at the Day Use Park were smaller than tagged fish released at the PUD Boat Launch based on weight $(t=-5.10, p$ $<0.0001)$ and fork length $(t=-4.78, p<0.0001)$ measurements. However, fish from the Day Use Park release groups were not tagged and released during most of July when fish were larger, on average (fig. 6). Statistical comparison of fish size during the period when both groups were being tagged and released (July 30-August 14,2014$)$ showed that fish weight $(t=0.17, p=0.868)$ and length $(t=0.47, p$ $=0.637$ ) were similar.

Reservoir travel time varied by release site, but forebay residence time was similar between groups. Forebay detection records show that 85 percent of the tagged fish (74 fish) released at the Day Use Park and 87 percent of the tagged fish released at the PUD Boat Launch (289 fish) arrived in the forebay of Cowlitz Falls Dam. The Day Use Park release site was located 2.7 rkm upstream of the PUD Boat Launch release site. Fish that were released at the Day Use Park had a slower median travel time $(2.3 \mathrm{~d})$ to the dam forebay than fish that were released at the PUD Boat Launch (1.0 d; fig. 7). Eventtime analysis showed that reservoir travel time differed between release sites $\left(X^{2}=7.5, p=0.006\right)$. Median forebay residence time was slightly less for fish released at the Day Use Park $(0.45 \mathrm{~d})$ than for fish released at the PUD Boat Launch $(0.60 \mathrm{~d})$, but these differences were not significant $\left(X^{2}=2.7, p=\right.$ 0.09; fig. 8).

Analysis of first detection events showed that juvenile Chinook salmon primarily arrived in deep zones $(>3.6 \mathrm{~m})$ and were dispersed across the face of the dam. Underwater antenna detection records showed that 88 percent of the fish from the Day Use Park (65 fish) and 85 percent of the fish from the PUD Boat Launch (246 fish) that arrived in the forebay were detected at the dam. Most tagged fish (80.6 percent; table 4) were first detected on antennas in the deep zone when they arrived at the dam, and this pattern did not vary by release site $(p=0.86)$. The largest percentage of fish from each release site were first detected at spillbay 1 and the lowest percentage of fish were first detected at spillbay 2 (table 4). These patterns did not vary by release site $(p=0.83)$. Although fish size and reservoir travel time differed by release site, forebay residence time, arrival depth, and horizontal arrival distributions were similar for fish from the two release sites. Given these findings, subsequent results have been pooled across release sites to simplify data presentation. 

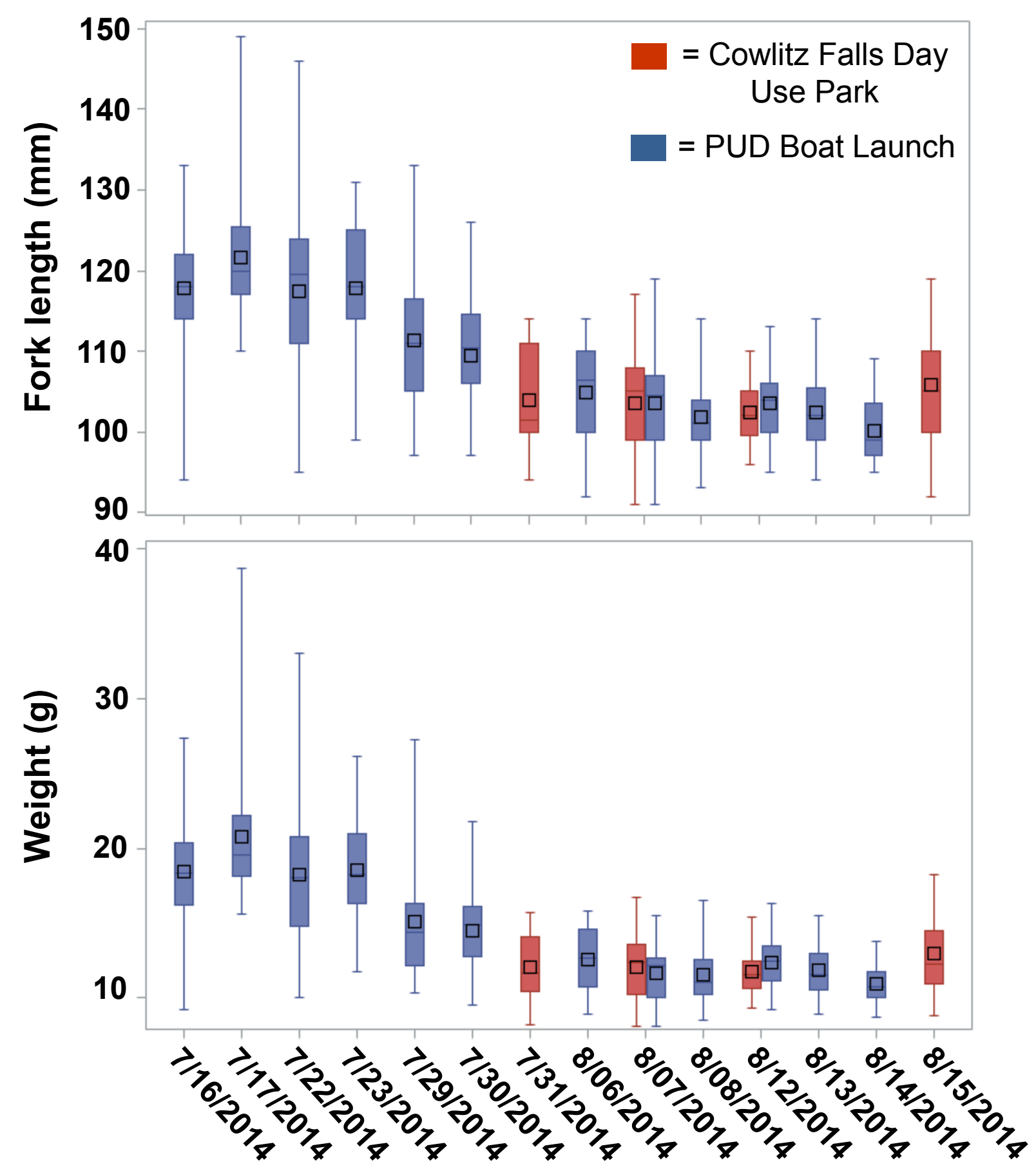

Figure 6. Boxplots showing juvenile Chinook salmon fork lengths in millimeters ( $\mathrm{mm}$ ) (top panel) and weights in grams (g) (bottom panel) for groups of fish that were tagged and released at the Cowlitz Falls Day Use Park and Lewis County Public Utility District (PUD) Boat Launch. Squares inside the box are the mean, lines inside the box are the median, box boundaries are the 25th and 75th percentiles, and whiskers are the minimum and maximum values for each group. 


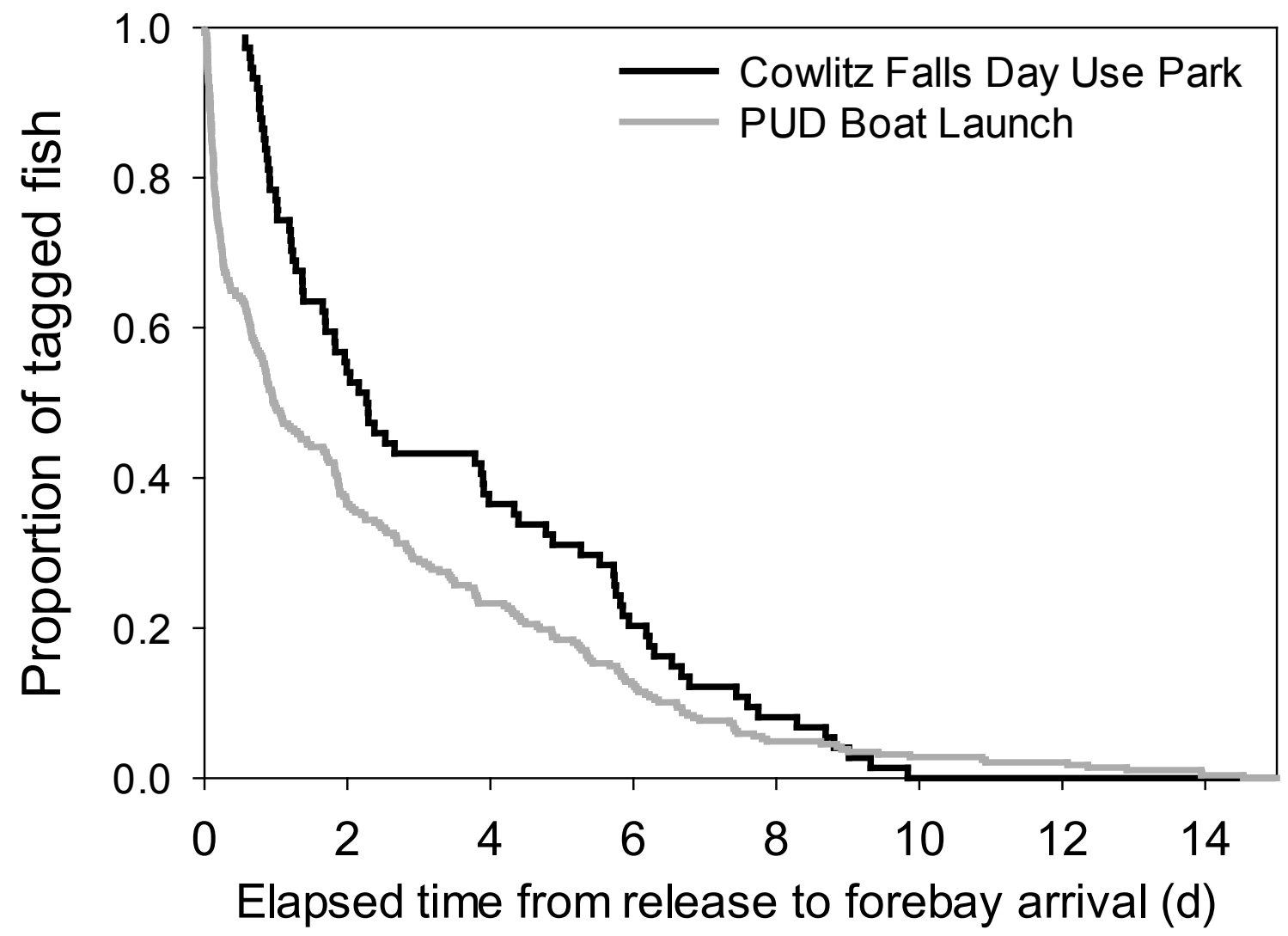

Figure 7. Graph showing proportion of tagged juvenile Chinook salmon that moved downstream from the Cowlitz Falls Day Use Park and Lewis County Public Utility District (PUD) Boat Launch release sites in Lake Scanewa and entered the forebay of Cowlitz Falls Dam over time (in days [d]). 


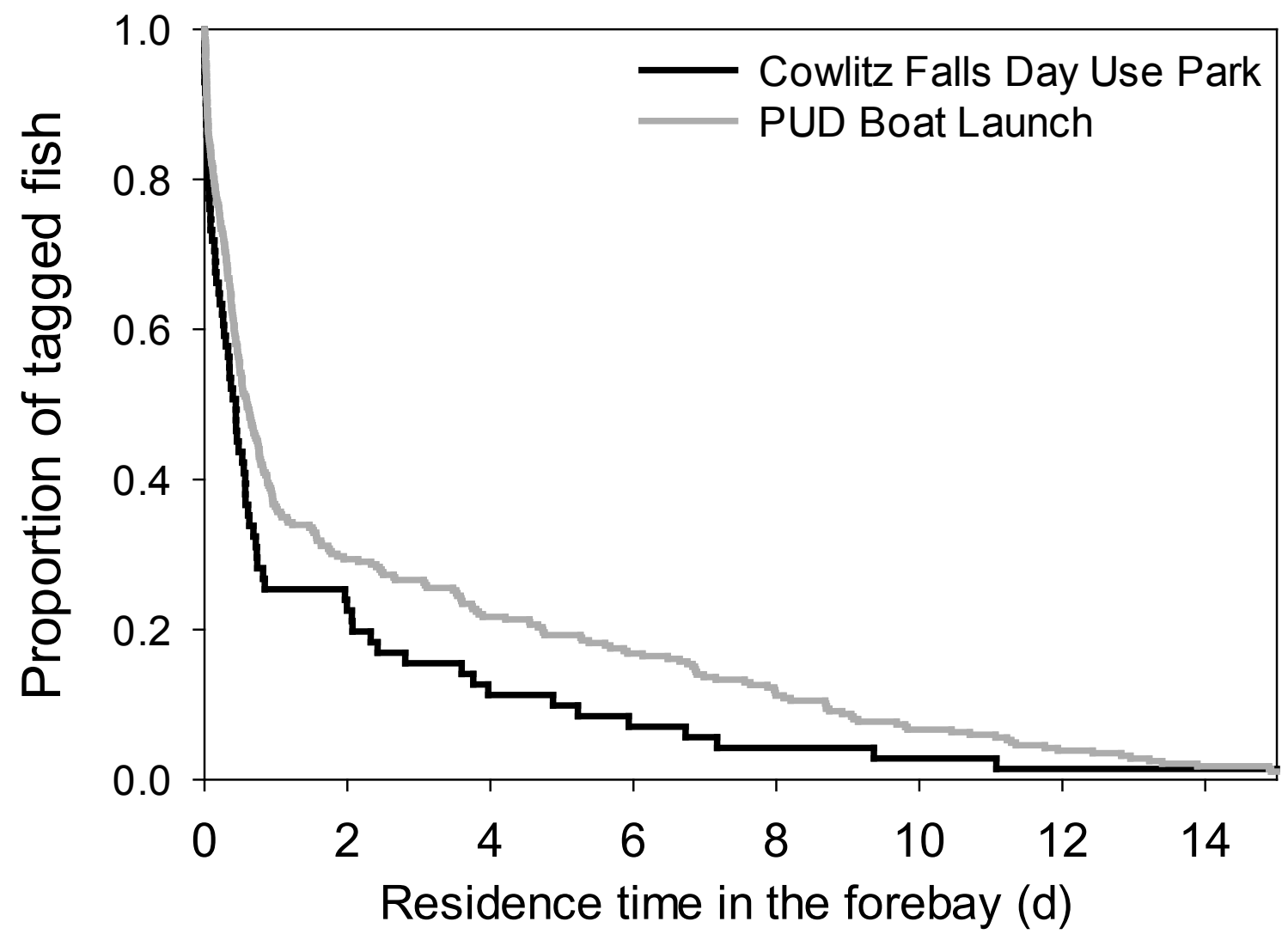

Figure 8. Graph showing residence time (in days [d]) of tagged juvenile Chinook salmon in the forebay of Cowlitz Falls Dam during July-August 2014 for groups of fish released at the Cowlitz Falls Day Use Park and the Lewis County Public Utility District (PUD) Boat Launch.

Table 4. Percentage of tagged juvenile Chinook salmon that were first detected in arrival zones that were horizontally and vertically stratified across the face of Cowlitz Falls Dam during 2014.

\begin{tabular}{|c|c|c|c|c|c|c|}
\hline Release site & Depth & Spillbay 1 & Spillbay 2 & Spillbay 3 & Spillbay 4 & Total \\
\hline \multirow[t]{2}{*}{ Cowlitz Falls Day Use Park } & Shallow & 9.4 & 0.0 & 1.6 & 9.4 & 20.3 \\
\hline & Deep & 26.6 & 12.5 & 26.6 & 14.1 & 79.7 \\
\hline Total & & 35.9 & 12.5 & 28.1 & 23.4 & \\
\hline Lewis County Public Utility & Shallow & 7.7 & 0.0 & 4.5 & 7.3 & 19.2 \\
\hline District Boat Launch & Deep & 31.7 & 14.6 & 18.7 & 15.4 & 80.8 \\
\hline Total & & 39.4 & 14.6 & 23.2 & 22.8 & \\
\hline \multirow[t]{2}{*}{ Overall } & Shallow & 8.1 & 0.0 & 3.5 & 7.7 & 19.4 \\
\hline & Deep & 30.6 & 13.9 & 20.6 & 15.5 & 80.6 \\
\hline Total & & 38.7 & 14.2 & 24.2 & 22.9 & \\
\hline
\end{tabular}




\section{Behavior Patterns, Performance Metrics, and Dam Passage}

A total of 363 tagged juvenile Chinook salmon ( 86 percent) were detected in the forebay of Cowlitz Falls Dam and 311 of these fish (86 percent) moved downstream and were detected on underwater antennas at the face of the dam (table 5). We examined arrival patterns on underwater antennas to determine if horizontal or depth distributions changed as the season progressed (table 6). Ninety-six tagged fish arrived at the dam during the first period (July 16-July 29), 103 tagged fish arrived during the second period (July 30-August 12), and 112 tagged fish arrived during the third period. There was no difference $(p=0.33)$ in horizontal arrival patterns between the three periods. The percentage of fish that arrived at the dam in the shallow zones was greater in the first period (27.4 percent) than in the second (14.6 percent) or third (17.0 percent) periods, but this difference was not quite statistically significant $(p=0.07$; table 6$)$. The lowest percentage of fish arrived in zones where collection entrances were located (shallow zones in spillbays 2 and 3 ) under all scenarios that we examined (tables 4 and 6).

About one-half of the tagged fish in the forebay eventually moved inside the debris barrier area (debris barrier discovery efficiency $=54$ percent; table 5), where the collection entrances were located. Dam operations during the study period primarily included the sole operation of turbine unit 2 (90 percent of the time), with the remaining operations consisting of no turbine operation ( 7 percent of the time) and sole operation of turbine unit 1 (3 percent of the time). The weir box discovery efficiency (76 percent) was greater than the flume 1 /flume 2 discovery efficiency ( 35 percent; table 5). Similarly, entrance efficiency was greater for the weir box ( 52 percent) than for flume 1/flume 2 ( 23 percent; table 5). However, flume 1/flume 2 retained every tagged fish that entered through those routes, whereas the weir box only retained 24 percent of the tagged fish that were detected inside the device (table 5). Capture efficiencies for both devices were low (5 percent or less; table 5).

Analysis of first detection events at collection entrances revealed that 91 percent of the tagged fish (143 fish) were first detected at the weir box, whereas the remaining fish initially arrived at entrances to flume 1/flume 2 ( 6 percent; 9 fish) or flume 4 ( 3 percent; 5 fish) (table 7 ). About one-half (52 percent) of the tagged fish that arrived at a collector entrance were only detected at the weir box, and most of the remaining fish (62 fish) were only detected at the weir box and the flume 1/flume 2 entrance (table 7). Some tagged fish made multiple trips between collection entrances, but most the tagged fish (80 percent) made three trips or less (fig. 9).

The largest percentage of tagged fish passed through turbines at Cowlitz Falls Dam and entered Riffe Lake (55 percent; table 8). Turbine passage was uncommon during daytime hours, and 87 percent of the passage occurred between the hours of 9:00 p.m. and 5:00 a.m. (fig. 10). The remaining fish either did not pass the dam (33 percent) or were collected (12 percent; table 8). Collection occurred through the weir box ( 5 percent), flume 1/flume 2 ( 4 percent), flume 4 ( 2 percent) or through an unknown route (1 percent; table 8 ). Collection occurred during daytime and nighttime hours, and peaked between the hours of 4:00 a.m. and 8:00 a.m. when 44 percent of the tagged fish were collected (fig. 10.)

Tagged fish that passed the dam moved quickly through the tailrace, and few of the fish discovered the URLC. The median travel time from tailrace entry to detection on the fixed site located $0.5 \mathrm{rkm}$ downstream of Cowlitz Falls Dam (downstream of the URLC) was $0.37 \mathrm{~h}$ (22.7 min), and 90 percent of the tagged fish moved through the URLC reach in $1.5 \mathrm{~h}$ or less. The discovery efficiency of the URLC was 10 percent; only 24 of the 230 tagged fish were detected at the entrance to the device. None of the tagged fish entered the URLC (entrance efficiency $=0$ percent) and no tagged fish were collected, so the remaining performance metrics for the device were not calculated. Tagged fish that discovered the URLC entrance were only briefly present at that location. Most of the tagged fish (22 
fish; 92 percent) had five detection events or less at the URLC entrance. The remaining two fish had 12 detections and 15 detections, respectively. Given that the transmitters emitted a signal every $3.5 \mathrm{sec}, 92$ percent of the tagged fish spent less than $20 \mathrm{sec}$ in the URLC discovery zone and none of the fish spent more than $1 \mathrm{~min}$ at that location.

Table 5. Summary of performance metrics for flume 1/flume 2 and the weir box at Cowlitz Falls Dam during 2014.

\begin{tabular}{lccc}
\hline \multicolumn{1}{c}{ Descriptor } & $\begin{array}{c}\text { Number of } \\
\text { fish }\end{array}$ & $\begin{array}{c}\text { Numbers in } \\
\text { calculation }\end{array}$ & Percent \\
\hline Number fish released & 421 & & \\
Number fish detected in forebay & 363 & $363 / 421$ & 86 \\
$\quad$ Number fish detected at face of dam & 311 & $311 / 363$ & 86 \\
$\quad$ Debris barrier discovery efficiency & & & \\
$\quad$ Number fish detected inside debris barrier area & 197 & $197 / 363$ & 54 \\
$\quad$ Flume and weirbox discovery efficiency & & & \\
$\quad$ Number fish detected within 6.1 meters of flume entrances & 69 & $69 / 197$ & 35 \\
$\quad$ Number fish detected within 6.1 meters of weir box & 149 & $149 / 197$ & 76 \\
$\quad$ entrance & & & \\
Flume and weirbox entrance efficiency & 16 & $16 / 69$ & 23 \\
$\quad$ Number fish detected inside flumes & 78 & $78 / 149$ & 52 \\
$\quad$ Number fish detected inside weir box & & & \\
$\quad$ Flume and weirbox retention efficiency & 16 & $16 / 16$ & 100 \\
$\quad$ Number fish collected in flumes & 19 & $19 / 78$ & 24 \\
$\quad$ Number fish collected in weir box & & & \\
Flume and weirbox capture efficiency & 16 & $16 / 363$ & 4 \\
$\quad$ Number fish collected in flumes & 19 & $19 / 363$ & 5 \\
$\quad$ Number fish collected in weir box & & & \\
\hline
\end{tabular}

Table 6. Percentage of tagged juvenile Chinook salmon that were first detected in arrival zones that were horizontally and vertically stratified across the face of Cowlitz Falls Dam during 2014.

[Data are pooled among release sites and presented by arrival date, which was determined by the date and time of first detection in one of the zones for each tagged fish]

\begin{tabular}{|c|c|c|c|c|c|c|}
\hline Arrival date & Depth & Spillbay 1 & Spillbay 2 & Spillbay 3 & Spillbay 4 & Total \\
\hline July 16-July 29 & Shallow & 12.6 & 0.0 & 5.3 & 9.5 & 27.4 \\
\hline & Deep & 29.5 & 14.7 & 16.8 & 11.6 & 72.6 \\
\hline Total & & 42.1 & 14.7 & 22.1 & 21.1 & \\
\hline July 30-August 12 & Shallow & 6.8 & 0.0 & 1.9 & 5.8 & 14.6 \\
\hline & Deep & 35.9 & 8.7 & 20.4 & 20.4 & 85.4 \\
\hline Total & & 42.7 & 8.7 & 22.3 & 26.2 & \\
\hline August 13 -August 26 & Shallow & 5.4 & 0.0 & 3.6 & 8.0 & 17.0 \\
\hline & Deep & 26.8 & 17.9 & 24.1 & 14.3 & 83.0 \\
\hline Total & & 32.1 & 17.9 & 27.7 & 22.3 & \\
\hline
\end{tabular}


Table 7. Summary of collection entrances where tagged fish were initially detected and total number of collection entrances where tagged fish were detected during the study.

[Numbers in parentheses are the percentage of each group]

\begin{tabular}{lc}
\hline \multicolumn{1}{c}{ Collection entrance } & Number of fish \\
\hline Collection entrance where fish were first detected & \\
Weir box & $143(91)$ \\
Flume 1/flume 2 & $9(6)$ \\
Flume 4 & $5(3)$ \\
\multicolumn{1}{l}{ Total $=$} & 157 \\
Collection entrance where fish were detected & \\
Weir box only & $81(52)$ \\
Weir box and flume 1/flume 2 & $62(39)$ \\
Flume 4 only & $5(3)$ \\
Weir box and flume 1/flume 2 and flume 4 & $4(3)$ \\
Flume 1/flume 2 only & $3(2)$ \\
Weir box and flume 4 & $2(1)$ \\
& \\
\hline
\end{tabular}

Table 8. Summary of fates of tagged juvenile Chinook salmon released upstream of Cowlitz Falls Dam during 2014.

[Numbers in parentheses are the percentage of each group]

\begin{tabular}{lc}
\hline \multicolumn{1}{c}{ Description } & Number of fish \\
\hline Total number of fish released & 421 \\
Total number of fish that did not pass the dam during the study & $141(33)$ \\
Total number of fish that passed through turbines at the dam & $230(55)$ \\
Total number of fish collected in the weir box & $19(5)$ \\
Total number of fish collected in flume 1/flume 2 & $16(4)$ \\
Total number of fish collected in flume 4 & $9(2)$ \\
Total number of fish collected through an unknown route & $6(1)$ \\
\hline
\end{tabular}




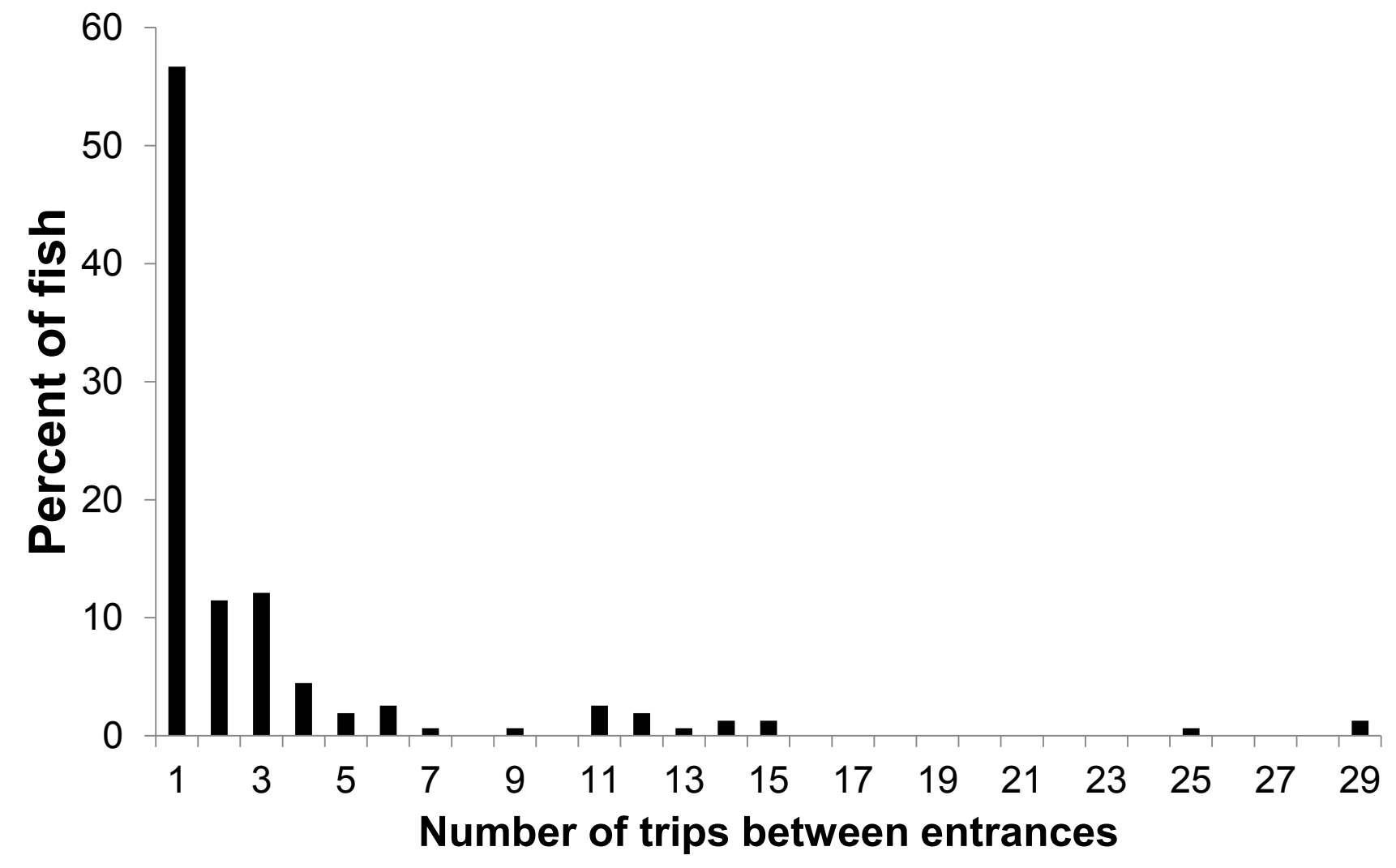

Figure 9. Graph showing percentage of tagged Chinook salmon that made trips between the collection entrances at Cowlitz Falls Dam during 2014. 


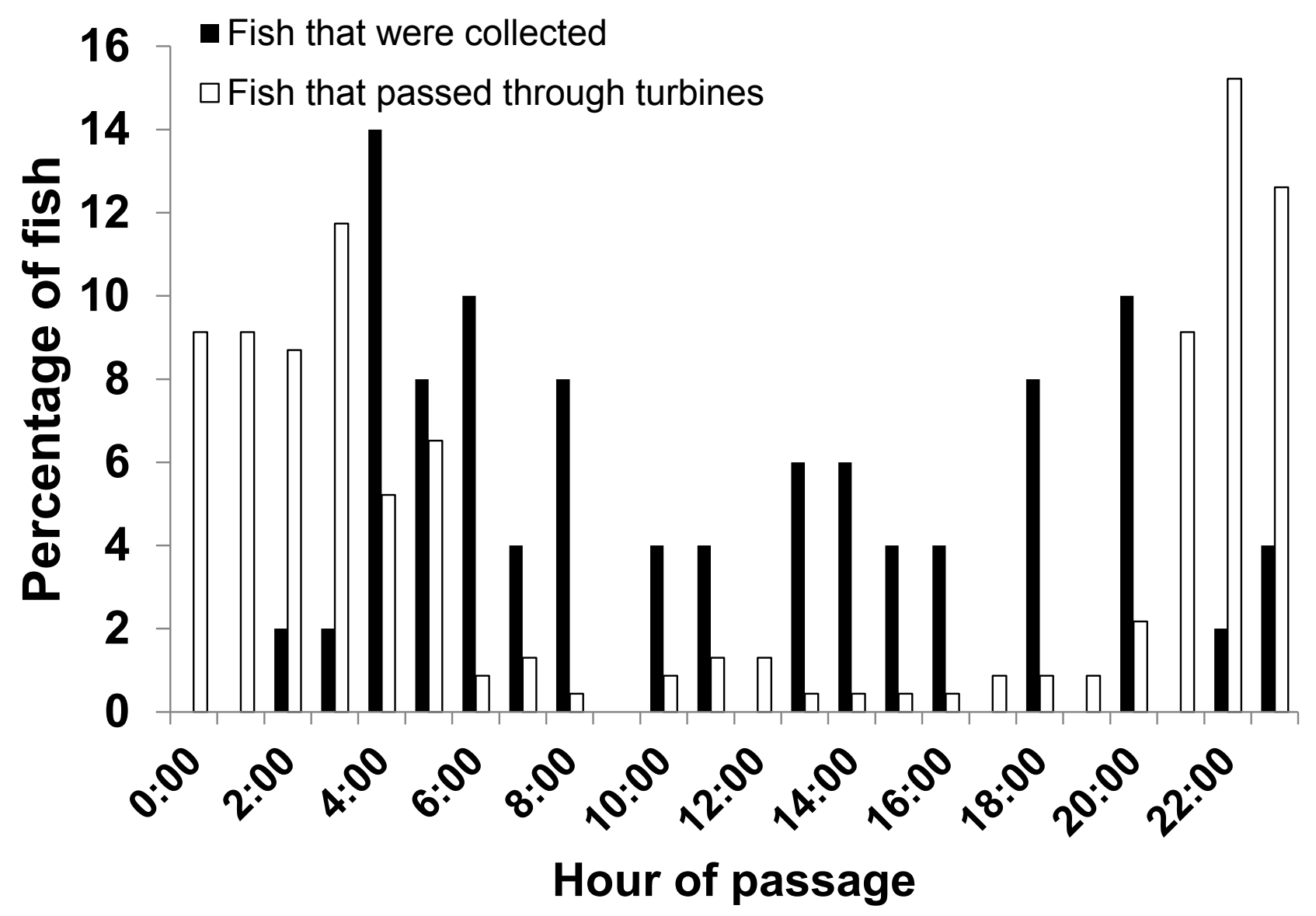

Figure 10. Graph showing percentage of tagged Chinook salmon that were collected (filled bars) or passed through turbines (open bars) by hour, at Cowlitz Falls Dam during 2014. 


\section{Discussion}

Behavior patterns of radio-tagged fish showed that a large percentage of the juvenile Chinook salmon were not susceptible to collection because many of the fish failed to pass Cowlitz Falls Dam during the study period. One-third of the tagged fish remained in Lake Scanewa, upstream of the dam, at the conclusion of the study. Similar results were observed in previous years when non-passage rates of juvenile Chinook salmon ranged from 11 to 43 percent (Kock and others, 2007, 2012; Liedtke and others, 2007, 2009, 2010). The fate of fish that remain upstream of Cowlitz Falls Dam is a critical uncertainty because little is known about these fish during September-April. Data from our research indicates that tagged fish are alive in Lake Scanewa during September, after the fish collection season, because tagged fish commonly are observed moving between areas where fixed sites are located (U.S. Geological Survey, unpub. data; September 2010). However, juvenile Chinook salmon were not monitored during October-April. Yearling Chinook salmon constitute a low proportion of the catch at the Cowlitz Falls Fish Facility each year (oral commun., John Serl, Washington Department of Fish and Wildlife; August 2012), which suggests that fish either are dying in Lake Scanewa, or are passing Cowlitz Falls Dam outside the fish collection season. Recent studies have shown that some juvenile Chinook salmon adopt alternate life history strategies in impounded reservoirs, and migrate downstream during the winter or following spring as yearlings (Keefer and others, 2012; Tiffan and others, 2012;). Because little is known about the fate of subyearling Chinook salmon in Lake Scanewa during September-April, this topic may be worthy of future evaluation.

Many juvenile Chinook salmon arrived at Cowlitz Falls Dam in zones that were deeper than the collection entrances, and the lowest percentage of tagged fish arrived in zones where the collection entrances were located. Most tagged fish (80 percent) that arrived at Cowlitz Falls Dam were first detected in deep zones where fish did not have access to collection entrances. The deep arrival patterns by tagged fish were expressed in passage distributions; 55 percent of the tagged fish passed through turbines and 2 percent of the tagged fish were collected through flume 4, after apparently entering spillbay 3 through the induction slots that were located in the turbine intake. Entry into spillbay 3 only could have occurred through the induction slots unless there were unknown gaps in the baffle panels at the upstream end of the spillbay. The presence of the debris barrier also may have affected the deep arrival patterns at the dam because fish that encountered the debris barrier would have had to sound underneath it before approaching the collection entrances. Arrival zones located inside the debris barrier area (shallow zones in spillbays 2 and 3 ) had the lowest percentage of arrival of all zones that were monitored. A total of eight arrival zones were available, and the shallow zones in spillbays 2 and 3 received 0 and 3.5 percent of the tagged fish that arrived at the dam, while the other zones received from 7.7 to 30.6 percent of the tagged fish (table 4). These data suggest that additional devices, such as guide nets and alterations to the debris barrier, may be necessary to concentrate juvenile Chinook salmon near surface collection entrances at Cowlitz Falls Dam. 
Cowlitz Falls Dam was operated to enhance discovery and collection rates of the weir box, and the device performed positively in several ways. Summer dam operations at Cowlitz Falls Dam generally consist of operating a single turbine unit because inflow levels are rarely high enough to simultaneously support operation of both units. Fishery managers generally believe that turbine flow guides fish as they approach the dam, which means that it may be possible to alter the number of fish that encounter spillbays 2 or 3 by selecting which turbine operates during a given period. Turbine 1 is located beneath spillbay 2 and turbine 3 is located beneath spillbay 3 , so the dam primarily was operated (90 percent of the time) using turbine 2 during our study to increase the number of fish that could encounter the device. Discovery efficiency of the weir box was high ( 76 percent), and 91 percent of the tagged fish that were detected near any of the collection entrances were first detected at the weir box. However, entrance efficiency and retention efficiency of the weir box were relatively low (52 and 24 percent, respectively), and the number of tagged fish that were collected through the weir box (19 fish) was similar to the number of tagged fish that were collected through flume 1/flume 2 (16 fish). If the weir box will be considered as a future collection option at Cowlitz Falls Dam, alterations to the flow rate and height of the weir crest may be necessary to increase entrance and retention characteristics of the device.

The performance of the weir box as a collection device for juvenile Chinook salmon was substantially different from the performance of the device when it was tested using juvenile steelhead and coho salmon during spring 2013. Weir box discovery efficiency was relatively high for steelhead (98 percent) and coho salmon (83 percent). However, all the steelhead and 95 percent of the coho salmon that were collected entered the collection system through flume 1/flume 2 rather than through the weir box (Kock and others, 2014). These data show differences that can occur between spring and summer collection efforts at Cowlitz Falls Dam and identify the importance of testing any new device across the entire range of collection conditions that occur during the fish collection season.

The use of tagged fish from two separate studies was instructive because it resulted in a substantial increase to the sample size for the study, and also shed light on potential differences in tagged fish behavior from two release sites. Inclusion of tagged fish from the Lewis County PUD study resulted in an almost five-fold increase to sample size compared to the original number of fish that were planned for the evaluation. Comparison of detection records between the two release groups suggested that few differences existed, although fish from the PUD Boat Launch were released closer to the dam. Overall, tagged fish from the Day Use Park releases were smaller than tagged fish from the PUD Boat Launch, but this was expected because tagging and release events from the first group were not conducted during July when larger fish were being collected (fig. 6). Fish size was similar between groups of fish that were tagged in August. We also determined that reservoir travel time was faster for the PUD Boat Launch group than for the Day Use Park group, but this also was expected because the release site was $2.7 \mathrm{rkm}$ closer to the dam. Tagged fish from the two release sites that arrived in the dam forebay had similar residence time and arrival distributions, which indicated that behavior patterns in the forebay were similar between groups. 
Data collected at the URLC suggest that discovery efficiency was very low (10 percent) and none of the tagged fish were detected inside the device. Efforts to increase URLC discovery efficiency would be the necessary first step towards improving collection in the device. The tailrace of Cowlitz Falls Dam, where the URLC was deployed, is a constricted channel; this can benefit collection efforts with the URLC because egress routes for juvenile salmon are limited. However, little is known about the horizontal or vertical distribution of juvenile salmon as they move downstream through the tailrace. Our data showed that tagged fish moved downstream through the tailrace fairly quickly (median travel time $=22.7 \mathrm{~min}$ ). This indicates the need to position the URLC effectively within the primary migration route of juvenile salmon because they are not present in the tailrace for long periods. Future studies to describe two- or three-dimensional movement paths of juvenile salmon in the tailrace of Cowlitz Falls Dam would likely provide the best information to guide URLC positioning efforts. After discovery rates are substantially increased, performance metrics such as entrance efficiency and retention efficiency can be used to better understand URLC performance.

\section{Acknowledgments}

Numerous people and entities contributed to this study. Tacoma Power provided funding for the project. Matt Bleich was our primary contact with Tacoma Power, and his thoughts and ideas contributed to the study design, analysis, and reporting. Logistical support was provided by Tacoma Power staff members Heather Daniels, Charles Dueber, and Ross Reichert at the Upper Riffe Lake Collector. Lewis County PUD purchased additional transmitters that were used in fish that we monitored during the evaluation. We thank John Serl and the staff of the Cowlitz Falls Fish facility for their efforts in collecting fish that were tagged for the study. Joe First, and his staff at Cowlitz Falls Dam, provided access and support that were necessary for the installation, operation, and maintenance of our equipment throughout the study period. Finally, reviews of this report by John Serl, Matt Bleich and Noah Adams were greatly appreciated.

\section{References Cited}

Adams, N.S., Johnson, G.E., Rondorf, D.W., Anglea, S.M., and Wik, T., 2001, Biological evaluation of the behavioral guidance structure at Lower Granite Dam on the Snake River, Washington in 1998: American Fisheries Society Symposium, v. 26, p. 145-160.

Allison, P. D. 1995. Estimating Cox regression models with PROC PHREG. Pages 111-184 in P.D. Allison, ed. Survival Analysis Using SAS: A Practical Guide. SAS Institute, Inc., Cary, North Carolina.

Coutant, C.C., 2001, Turbulent attraction flows for guiding juvenile salmon at dams: American Fisheries Society Symposium, v. 26, p. 55-57.

Coutant, C.C., and Whitney, R.R., 2000, Fish behavior in relation to passage through hydropower turbines-A review: Transactions of the American Fisheries Society, v. 129, p. 351-380.

Evans, S.D., Adams, N.S., Rondorf, D.W., Plumb, J.M., and Ebberts, B.D., 2008, Performance of a prototype surface collector for juvenile salmon at Bonneville Dam's first powerhouse on the Columbia River, Oregon: River Research and Applications, v. 24, p. 960-974.

Farley, J.M., Perry, R.W., Shurtleff, D.J., Feil, D.H., and Rondorf, D.W., 2003, Migration behavior of juvenile salmon and evaluation of a modified flume entrance at Cowlitz Falls Dam, Washington, 2001: Report by the U.S. Geological Survey to the Public Utility District No. 1 of Lewis County, $51 \mathrm{p}$. 
Haro, A., Odeh, M., Noreika, J., and Castro-Santos, T., 1998, Effect of water acceleration on downstream migratory behavior and passage of Atlantic salmon juvenile salmon and juvenile American shad at surface bypasses: Transactions of the American Fisheries Society, v. 127, p. 118127.

Hausmann, B.J., Feil, D.H., and Rondorf, D.W., 2001, Evaluation of an experimental baffle panel configuration to improve fish collection efficiency at Cowlitz Falls Dam, Washington, spring 2000: Report by the U.S. Geological Survey to the Public Utility District No. 1 of Lewis County, 16 p. Johnson, G.E., and Dauble, D.D., 2006, Surface flow outlets to protect juvenile salmon passing through hydropower dams: Reviews in Fisheries Science, v. 14, p. 213-244.

Keefer, M.L., Taylor, G.A., Garletts, D.F., Helms, C.K., Gauthier, G.A., Pierce, T.M., and Caudill, C.C., 2012, Reservoir entrapment and dam passage mortality of juvenile Chinook salmon in the Middle Fork Willamette River: Ecology of Freshwater Fish, v. 21, p. 222-234.

Kock, T.J., Liedtke, T.L., Ekstrom, B.K., Tomka, R.G., and Rondorf, D.W., 2012, Behavior and passage of juvenile salmon during evaluation of a behavioral guidance structure at Cowlitz Falls Dam, Washington, 2011: U.S. Geological Survey Open-File Report 2012-1030, 96 p., http://pubs.usgs.gov/of/2012/1030/.

Kock, T.J., Liedtke, T.L., Ekstrom, B.K., Tomka, R.G., and Rondorf, D.W., 2014, Evaluation of juvenile salmonid behavior near a prototype weir box at Cowlitz Falls Dam, Washington, 2013: U.S. Geological Survey Open-File Report 2014-1042, 24 p., http://pubs.usgs.gov/of/2014/1042/.

Kock, T.J., Liedtke, T.L., Kritter, M.A., and Rondorf, D.W., 2007, Behavior and passage of juvenile salmon during evaluation of a new fish screen at Cowlitz Falls Dam, 2006: Report by the U.S. Geological Survey to Tacoma Power, 46 p.

Liedtke, T.L., Beeman, J.W., and Gee, L.P., 2012, A standard operating procedure for the surgical implantation of transmitters in juvenile salmon: U.S. Geological Survey Open-File Report 2012-1267, 50 p., http://pubs.usgs.gov/of/2012/1267/.

Liedtke, T.L., Kock, T.J., Ekstrom, B.K., and Rondorf, D.W., 2009, Behavior and passage of juvenile salmon during the evaluation of a fish screen at Cowlitz Falls Dam, Washington, 2008: Report by the U.S. Geological Survey to Tacoma Power, 33 p.

Liedtke, T.L., Kock, T.J., Ekstrom, B.K., Royer, I.M., and Rondorf, D.W., 2010, Juvenile salmonid collection efforts in the upper Cowlitz River Basin-2009 evaluations: Report by the U.S. Geological Survey to Tacoma Power, 135 p.

Liedtke, T.L., Kock, T.J., Kritter, M.A., Ekstrom, B.K., and Rondorf, D.W., 2007, Behavior and passage of juvenile salmon during evaluation of a fish screen at Cowlitz Falls Dam, 2007: Report by the U.S. Geological Survey to Tacoma Power, 49 p.

Perry, R.W., Braatz, A.C., Farley, M.J., and Rondorf, D.W., 2004, Migration behavior of juvenile salmon and evaluation of a modified box entrance at Cowlitz Falls Dam, Washington, 2003: Annual report by the U.S. Geological Survey and Washington Department of Fish and Wildlife; page 54. Serl, J.D., and Heimbigner, D., 2014, Data summary for the 2013 operation of the Cowlitz Falls fish facility and related activities: Report by the Washington Department of Fish and Wildlife and the Pacific States Marine Fisheries Commission to the Bonneville Power Administration, 51 p. 
Sokal, R.R., and Rohlf, J.F., 1994, Biometry-The Principles and Practice of Statistics in Biuological Research: San Francisco, W. H. Freeman and Company, 880 p.

Tiffan, K.G., Kock, T.J., Connor, W.P., Mullins, F., and Steinhorst, R.K, 2012, Downstream movement of fall Chinook salmon juveniles in the Lower Snake River reservoirs during winter and early spring: Transactions of the American Fisheries Society, v. 141, p. 285-293.

Tiffan, K.G., Kock, T.J., Haskell, C.A., Connor, W.P., and Steinhorst, R.K., 2009, Water velocity, turbulence, and migration rate of subyearling fall Chinook salmon in the free-flowing and impounded Snake River: Transactions of the American Fisheries Society, v. 138, p. 373-384. 
Publishing support provided by the U.S. Geological Survey

Science Publishing Network, Tacoma Publishing Service Center

For more information concerning the research in this report, contact the Director, Western Fisheries Research Center U.S. Geological Survey

6505 NE 65th Street

Seattle, Washington 98115

http://wfrc.usgs.gov/ 


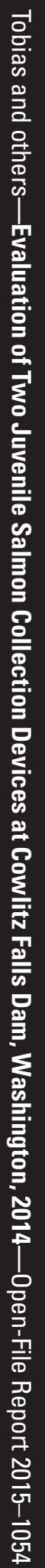

